\title{
THE EU AND ITS MEMBER STATES IN THE WTO DISPUTE SETTLEMENT: A 'Competence Model', or A Case Apart, for Managing International Responsibility?
}

\section{Gracia Marín Durán}

Forthcoming in M. Cremona, A. Thies and R. Wessel, The EU and International Dispute Settlement (Hart Publishing, 2016).

(DRAFT)

\section{1) INTRODUCTION}

The aim of this chapter is to examine and assess the participation of the European Union (EU) and its Member States (MS) in the dispute settlement system of the World Trade Organisation (WTO), with a focus on one legally and politically important question: how their unique position as full WTO members has affected their respective responsibility for the performance of WTO obligations. As it is the case for any other 'mixed' agreement, this joint EU/MS membership of the WTO inevitably prompts the question of 'who is responsible' towards third parties for breaches of WTO law. The question of the EU's international responsibility vis-à-vis that of its Member States has been the subject of intense study in the past years, ${ }^{1}$ partly due to the increasingly prominent role of the Union on the international scene but also the work of the International Law Commission (ILC) on the Draft Articles on the Responsibility of International Organisations. ${ }^{2}$ And yet within this broader debate, the WTO is often presented in the academic literature as providing both an 'exceptional' and 'exemplary' case-study.

Not only is the WTO one of the rare international fora in which the EU can fully participate as a party in dispute settlement proceedings, but the Union -perhaps not surprisingly as one of the world's leading trade powers- has actually been one of the dominant players in the WTO dispute settlement system: out of the total 496 disputes that have been brought for resolution to the WTO since 1995, the EU (alone) has participated in 312 of them. ${ }^{3}$ Therefore, in the context of the WTO dispute settlement system, the question of EU/MS international responsibility is not only of theoretical significance, but also highly relevant in practice. Moreover, the active participation of the EU in the WTO dispute settlement system has been praised as constituting an example of its international actorness and leadership: in fact, the Union has been eager to come forward as single litigant and to assume sole responsibility in WTO disputes, even for alleged breaches by its Member States. Against this background, it has been argued that WTO dispute settlement practice shows how the duty of cooperation (Article 4(3) TEU) has allowed the EU to speak with one unified voice, with that voice being the European Commission as porte-parole for the Union. ${ }^{4}$

\footnotetext{
${ }^{1}$ See e.g., E. Evans and P. Koutrakos (eds.), The International Responsibility of the European Union - European and International Perspectives (Hart, 2013); and further references in section 2 below.

2 Draft Articles on the Responsibility of International Organizations, annexed to UNGA Res 66/100, UN Doc A/Res/66/100, 27 February 2012 [hereinafter, DARIO].

3 See WTO, 'Disputes by Country/Territory', at: https://www.wto.org/english/tratop e/dispu e/dispu by country e.htm, last visited on 16 June 2015.

${ }^{4}$ See e.g., A. Delgado Casteleiro and J. Larik, 'The 'Odd Couple': Responsibility of the EU at the WTO' in E. Evans and P. Koutrakos (eds.), The International Responsibility of the European Union - European and International Perspectives (Hart, 2013), at 252 and 254-255; P. Eeckhout,'The EU and its Member States in the WTO-Issues of Responsibility' in L Bartels and F Ortino (eds), Regional Trade Agreements and the WTO Legal System (Oxford University Press, 2006), at 6-7. That being said, EU Member States have of course continued to exert considerable influence over the conduct of WTO litigation through internal institutional structures (notably, the Council and the Trade Policy Committee; see Articles 207(3) and 218(9) TFEU), and worked closely with the
} 
While generally upholding this prevailing view that the EU's participation in the WTO dispute settlement system has been a 'success story', this chapter will offer a more nuanced assessment of the Union's eagerness to assume lead responsibility for breaches of WTO law, in terms of both the degree of third-party acceptance and the relative impact of EU own rules. After outlining the theoretical questions of international responsibility stemming from the parallel EU/MS membership of the WTO (section 2), the chapter will proceed to analyse how this issue has been tackled in the practice of WTO dispute settlement. Drawing upon this indepth analysis of practice, two main arguments will be advanced. First, the extent to which the EU's assertion of exclusive participation and responsibility has been accepted by other W'TO members and dispute settlement organs ought to be qualified, particularly in light of more recent, post-Lisbon, WTO disputes (section 3). Second, the approach to EU/MS international responsibility we have witnessed in the WTO dispute settlement system has not just been determined by the EU internal rules -i.e., a pure 'competence model', whereby the exclusive (external) competence of the EU for virtually all WTO matters will implicate its exclusive responsibility in all instances. ${ }^{5}$ Rather, the specificity of the WTO dispute settlement system has exercised considerable influence on whether and how such internal rules are relevant to the determination of EU (sole or joint) responsibility for breaches of WTO law, and most significantly the WTO rules on remedies which embody the very purpose of assigning responsibility for an internationally wrongful act in this specific treaty context. Accordingly, it is suggested that this 'competence/remedy' model for managing EU/MS international responsibility in the WTO, which combines both internal and external legal factors, may remain a case apart, unique to that dispute settlement regime (section 4).

\section{2) EU/MS JOINT MEMBERSHIP IN WTO - QUESTIONS OF RESPONSIBILITY IN THEORY}

\subsection{WTO Agreement as a 'mixed agreement'}

As it is well-known, the (umbrella) Agreement establishing the World Trade Organisation (or WTO Agreement) ${ }^{6}$ was jointly concluded by the EU and its Member States following the famous Opinion 1/94, where the EU Court of Justice ruled that the Union ${ }^{8}$ had exclusive competence to conclude only the multilateral agreements on trade in goods (Annex 1A), whereas such external competence was shared with the Member States in relation to the General Agreement on Trade in Services (GATS) and the Agreement on Trade-Related

European Commission in preparing the 'Union's defence': see P.J. Kuijper, 'International Responsibility for EU Mixed Agreements' in C Hillion and P Koutrakos (eds), Mixed Agreements Revisited: The EU and Its Member States in the World (Oxford, Hart Publishing, 2010), at 224.

${ }^{5}$ This 'competence model', with specific reference to the WTO dispute settlement system, is proposed in P.J. Kuijper and E. Paasivirta, 'EU International Responsibility and its Attribution: From the Inside Looking Out' in E. Evans and P. Koutrakos (eds.), The International Responsibility of the European Union - European and International Perspectives (Hart, 2013), at 54-63, and further discussed in section 4.1 below.

6 Marrakesh Agreement Establishing the World Trade Organization, 15 April 1994, 1867 U.N.T.S. 154 [hereinafter, WTO Agreement], which serves as an umbrella agreement for: (i) 13 multilateral agreements on trade in goods (Annex 1A); (ii) General Agreement on Trade in Services (Annex 1B); Agreement on TradeRelated Aspects of Intellectual Property Rights (Annex 1C); Understanding on the Rules and Procedures Governing the Settlement of Disputes (Annex 2); Trade Policy Review Mechanism (Annex 3); and several plurilateral agreements (Annex 4).

7 Opinion 1/94 (re WTO Agreement) [1994] ECR I-5267.

${ }^{8}$ For the benefit of simplification, this chapter will refer to the European Union only, even though Opinion 1/94 concerned the then 'European Community', and indeed it is the 'European Communities' that formally became a member of the WTO (see n 10 below). 
Aspects of Intellectual Property Rights (TRIPS). ${ }^{9}$ This is reflected in Article XI:1 WTO Agreement, which refers to the EU and its Member States as full 'original members' in their own right. ${ }^{10}$ Like for any other so-called 'mixed' agreement, this joint EU/MS membership of WTO inevitably prompts the question as to 'who is responsible' towards third parties in situations of non-performance. However, the WTO Agreement is somehow unusual when compared to other multilateral 'mixed' agreements, in that it does not contain any 'Declaration of Competences', ${ }^{11}$ and thus there is no indication as to which part of the WTO Agreement (and its covered agreements) binds the Union and which the Member States. In other words, there is no express delimitation of their respective responsibility in relation to the performance of WTO obligations. ${ }^{12}$

Against this silence in the WTO Agreement, the general rules of international responsibility as codified by the International Law Commission ${ }^{13}$ provide that the existence of an internationally wrongful act entailing international responsibility depends on the twin conditions of breach of an international obligation and attribution of conduct. ${ }^{14}$ Applying this to our case-study raises, in turn, two questions: (i) how to apportion international obligations as between the EU and its Member States under a 'mixed' treaty such as the WTO Agreement; and (ii) when may conduct ${ }^{15}$ of the EU Member States which violates W'TO law be attributed to the Union (and vice-versa). A sticky point in the discussions leading up to the drafting of the DARIO was, however, whether the 'rules of the organisation' -and in particular, the internal delimitation of powers- should play a role in determining the respective international responsibility of an international organisation and its members. While it is not the purpose of this chapter to paint a complete portrait of this theoretical debate, ${ }^{16}$

${ }^{9}$ For a detailed discussion, see inter alia J.H. Bourgeois, 'The EC in the WTO and Advisory Opinion 1/94: an Echternach Procession' (1995) 32 Common Market Law Review 763; A. Burnside, 'The Scope of the Common Commercial Policy Post Opinion 1/94: Clouds and Silver Linings' in A. Dashwood and C. Hillion (eds.), The General Law of EC External Relations (Sweet\&Maxwell, 2000); N. Emiliou, 'The Death of Exclusive Competences?’ (1996) 21 European Law Review 2 (1996) 294.

10 Article XI:1 WTO Agreement, reads: "The contracting parties to GATT 1947 as of the date of entry into force of this Agreement, and the European Communities, which accept this Agreement and the Multilateral Trade Agreements and for which Schedules of Concessions and Commitments are annexed to GATT 1994 and for which Schedules of Specific Commitments are annexed to GATS shall become original Members of the WTO."

${ }^{11}$ For a critical review, see A. Delgado Casteleiro, 'EU Declarations of Competence to Multilateral Agreements: A Useful Reference Base?’ (2012) 17(4) European Foreign Affairs Review 491; J. Heliskoski, 'EU Declarations of Competence and International Responsibility' in E. Evans and P. Koutrakos (eds.), The International Responsibility of the European Union - European and International Perspectives (Hart, 2013).

${ }^{12} C f$ with United Nations Convention on the Law of the Sea, 10 December 1982, 1833 UNTS 3, Annex IX, Articles 5 and 6, whereby the extent of the respective powers of an international organisation and its member States (as notified under the Convention) determines the extent of their respective responsibilities for breaches of the Convention.

13 Articles on Responsibility of States for Internationally Wrongful Acts, annexed to UNGA Res 56/83, UN Doc A/RES/56/83, 12 December 2001 [hereinafter, ARS]; and DARIO (n 2 above).

14 Article 2 ARS; Article 4 DARIO.

${ }^{15}$ In this paper, the term 'conduct' is interchangeably used with the term 'measure', which in the context of the W'TO dispute settlement system equally means 'any act or omission attributable to a W'TO Member': US Corrosion-Resistant Steel Sunset Review, Report of the Appellate Body, WT/DS244/AB/R, adopted 9 January 2004, para 81.

${ }^{16}$ See further, J. d' Aspremont, 'A European Law of International Responsibility? The Articles on the Responsibility of International Organisations and the EU' in V. Kosta, N. Skoutaris and V. Tzevelekos (eds.), The EU Accession to the ECHR (Hart, 2014); F. Hoffmeister, 'Litigating against the European Union and Its Member States - Who Responds under the ICL's Draft Articles on International Responsibility of International Organizations?' (2010) 21(3) European Journal of International Law 723; E. Paasivirta and P. J. Kuijper, 'Does One Size Fit All? The European Community and the Responsibility of International Organizations' (2005) XVVI Netherlands Yearbook of International Law 169; S. Talmon, 'Responsibility of International Organisations: Does the 
the main contrasting positions will be briefly outlined below as a backdrop to the subsequent analysis of practice in the WTO dispute settlement system.

\subsection{Question of Apportionment of Obligations}

As they currently stand, the general rules of international responsibility do not specifically address the question of determining the respective obligations of an international organisation and its members in cases where both are parties to an international treaty, such as the WTO Agreement for the EU and its Member States. ${ }^{17}$ In this respect, the European Commission's position, as elaborated in its submissions on the DARIO to the ILC, has been that the question of apportionment of international obligations should be "entirely determined by the rules of the organisation, since these rules define the tasks and powers of the organisation which possesses its own international legal personality, vis-à-vis those of the member States." ${ }^{18}$ Moreover, the EU takes the view that apportionment of obligations "is really the primary question" and should be clearly distinguished from the secondary question of attribution of conduct. ${ }^{19}$

Applying this line of reasoning to the case of the WTO, this would mean looking at EU rules on the division of external (i.e., treaty-making) powers in order to determine whether a particular WTO obligation has been entered into by the Union or its Member States. However, given the dynamic and blurry delineation of external competences, it is hardly realistic to expect WTO dispute settlement organs to engage with such complex questions of EU law, nor does it seem desirable from the perspective of safeguarding the 'autonomy' of the EU legal order. ${ }^{20}$ Arguably, this issue has now become less complicated with the entry into force of the Lisbon Treaty, ${ }^{21}$ by virtue of which the Union has acquired exclusive external competence for quasi all matters presently regulated by WTO law. ${ }^{22}$ Following the Commission's view, this would imply that, as the sole bearer of WTO obligations in a postLisbon setting, only the EU is capable of incurring international responsibility in the WTO. If this is so, there would be no need to consider the question of attribution: for the Commission, it is impossible that a wrongful act can still be attributed to the EU Member States, once it has been established they are no longer carriers of the relevant WTO

European Community require Special Treatment?' in M. Ragazzi (ed.), International Responsibility Today: Essays in memory of Oscar Schachter (Matinus Nijhoff, 2005).

17 See Article 11 DARIO; Articles 12-13 ARA.

18 ILC, 'Responsibility of International Organisations - Comments and Observations received from International Organisations', Doc A/CN.4/545, dated 25 July 2004 [hereinafter DARIO Comments 2004], at 26 (para. 2). This seems also the view taken by Advocate General Mischo in Case C - 13/00 Commission $v$ Ireland [2002] ECR I-2923, para. 30 of the Opinion; as well as by Paasivirta and Kuijper (2005), at 216.

${ }^{19}$ DARIO Comments (2004), at 26 (para. 3).

${ }^{20}$ For a similar view, see Eeckhout (2006), at 9.

${ }^{21}$ Article 3(1)(e) TFEU.

22 Except for transport services (Article 207(5) TFEU). With regards to the TRIPS Agreement, see Case C414/11 Daïchi Sankyo and Sanofi-Aventis Deutschland, judgement of 18 July 2013 (not yet reported), paras. 45-61, where the Court upheld the Commission's view that, following the entry into force of the Lisbon Treaty, the TRIPS Agreement as a whole now falls within the EU's exclusive external competence under the CCP, even though the specific subject of patentability at issue (Article 27 TRIPS) is covered by shared competence in the field of the internal market (Articles 114 and 118 TFEU). See generally, P. Eeckhout, EU External Relations Law (Oxford University Press, 2nd edition, 2011), chapter 2; and F. Hoffmeister, 'The European Union's Common Commercial Policy a year after Lisbon-Sea Change or Business as Usual?’ in P. Koutrakos (ed), The European Union's External Relations a Year after Lisbon (CLEER Working Paper 2011/3), at 83-84. 
obligations. ${ }^{23}$ Even if one accepts that this proposition is true as a matter of EU (competence) law, it is not equally valid under public international law. ${ }^{24}$

From an international law perspective, so long as both the EU and its Member States remain parties to the WTO Agreement (and its covered agreements), the presumption is that they are each bound by all obligations therein ${ }^{25}$ and may not invoke internal rules as justification for non-performance ${ }^{26}$ unless it is otherwise agreed in the treaty or in situations covered by Article 46 VCLTIO. However, as already mentioned, there is no 'Declaration of Competences' or any other textual basis in the WTO Agreement for apportioning obligations and responsibility as between the EU and its Member States. ${ }^{27}$ In addition, it is doubtful that Article 46 VCLTIO could be invoked in this case: ${ }^{28}$ given the ambiguity as to the division of competences between the EU and its Member States prevailing at the time when the WTO Agreement was concluded, a violation of the rules of the organisation could not have been "manifest" (i.e., objectively evident) to third parties. ${ }^{29}$ Consequently, the majority of the

23 DARIO Comments (2004), at 26, para. 4-5, applying this reasoning to customs matters.

${ }^{24}$ See on this point, Advisory Opinion of Advocate General Tesauro in Case C - 53/96 Hermes International $v$. FHT Marketing [1998] ECR I-3603, para. 14: "This is how matters stand on the Community side but it must not be forgotten that both the Community and the Member States signed all the WTO agreements and are therefore contracting parties vis-à-vis contracting non-member States. And while it is true that the approval of those agreements on behalf of the Community is restricted to 'matters within its competence', it is also true that the Final Act and the WTO Agreement contain no provisions on competence and the Community and its Member States are cited as original members of equal standing. In these circumstances, it should be recognised that the Member States and the Community constitute, vis-à-vis contracting non-member States, a single contracting party or at least contracting parties bearing equal responsibility in the event of failure to implement the agreement. This clearly means that, in that event, the division of competence is a purely internal matter."

25 This flows from the principle of pacta sunt servanda in Article 26 of the Vienna Convention on the Law of Treaties between States and International Organisations or between International Organisations, 21 March 1986 (not yet in force) [hereinafter, VCLTIO].

26 Article 27 VCLTIO.

27 The only caveat to be noted in this regard is the GATS Schedule of Specific Commitments: the EU Schedule currently in force only covers the 12 Member States in 1994, while those that have later acceded to the EU have their own Schedules. See, WTO, 'European Communities and Their Member States - Schedule of Specific Commitments' (GATS/SC/31), dated 15 April 1994; and for the Services Schedules of the other 16 EU Member States: https://www.wto.org/english/tratop e/serv e/serv commitments e.htm.

Following these successive enlargements, the EU has entered into negotiations on compensatory adjustment with other WTO members pursuant to Article V:5 GATS. However, the resulting Consolidated Schedule of Specific Commitments of the EU and its Member States has not yet entered into force: see WTO, 'Communication from the European Communities and its Member States - Draft Consolidated GATS Schedule' (S/C/W/273), dated 9 October 2006. Accordingly, at the time of writing, the 16 Member States that acceded to the EU after 1994 are still bound by their individual Schedules of Specific Commitments, which has implications not only for their market access obligations (Article XVI GATS), but also other obligations in the GATS that are applicable only to the extent that a WTO member has undertaken specific commitments in its Schedule (notably, Article XVII GATS on national treatment, as well as e.g., Article VI:1 and VI:5 GATS on domestic regulation).

${ }_{28}$ Article 46(2) VCLTIO provides: "An international organization may not invoke the fact that its consent to be bound by a treaty has been expressed in violation of the rules of the organization regarding competence to conclude treaties as invalidating its consent unless that violation was manifest and concerned a rule of fundamental importance." Article 46(3) VCLTIO further states: "A violation is manifest if it would be objectively evident to any State or any international organization conducting itself in the matter in accordance with the normal practice of States and, where appropriate, of international organizations and in good faith." (emphasis added).

${ }^{29}$ For a similar view, see Eeckhout (2006), at 3 noting that, due to the sequence of events, some WTO members may in fact have signed and approved the WTO Agreement before Opinion 1/94 was delivered; and E. Steinberger, 'The WTO Treaty as a Mixed Agreement: Problems with the EC's and the Member States' Membership of the WTO' (2006) 17(4) European Journal of International Law 837, at 842-848 and 856-857. For a different view, see M Björklund, 'Responsibility of the EC and the Member States for Mixed Agreements Should Non-Member Parties Care? (2001) 70(30) Nordic Journal of International Law 373, at 388-402. For a criticism, see L. Bartels, Human Rights Conditionality in the EU's International Agreements (OUP, 2005), at 153. 
academic literature adopts the view that the EU and its Member States are jointly bound by all provisions of WTO law. ${ }^{30}$ But does this mean there would be joint responsibility of the EU and its Member States for breaches of WTO law in each and every case? That is not a foregone conclusion: being bound by the same WTO obligation is a necessary, but not a sufficient, condition for the joint responsibility of the EU and its Member States. ${ }^{31}$ In the logic of the system of international responsibility as codified by the ILC, breach of an obligation needs to be supplemented by attribution, and therefore the key question is whether the WTO-infringing conduct is attributable to the EU and/or its Member States.

\subsection{Question of Attribution of Conduct}

Unlike for the issue of apportionment, the general rules of international responsibility deal specifically with the attribution of conduct to an international organisation. ${ }^{32}$ Article 6 DARIO provides that conduct of an organ or agent of an international organisation shall be attributed to it, while Article 7 DARIO extends such an attribution to the organisation for the conduct of an organ of a State in cases where it is 'placed at the disposal of the organisation and if the latter exercises 'effective control' over such conduct. However, the European Commission and some scholars have argued that these attribution rules are not flexible enough to accommodate the distinctive traits of the Union's constitutional structure and functioning. ${ }^{33}$

This concern is not entirely misplaced, as applying the DARIO rules on attribution to the EU/MS relationship would limit the situations in which the Union incurs (sole) responsibility for breaches of WTO law. ${ }^{34}$ Due to the multilevel and decentralised implementation of most areas of EU law (i.e., so-called 'executive federalism'), ${ }^{35} \mathrm{EU}$ organs directly implement only a limited (even if important) segment of the common commercial policy (CCP) -i.e., trade defence measures, ${ }^{36}$ which are clearly attributable to the Union via Article 6 DARIO. For other areas of the CCP, the Union is largely dependent on its Member States to execute EU

30 See inter alia, M. Cremona, 'External Relations of the EU and the Member States: Competence, Mixed Agreements, International Responsibility and Effects of International Law, EUI Working Papers Law No 2006/22; G. Gaja, 'The European Community's Rights and Obligations under Mixed Agreements' in D. O'Keeffe and H.G. Schermers (eds.), Mixed Agreements (Kluwer, 1983); E. Neframi, 'International Responsibility of the European Community and of Member States under Mixed Agreements' in E. Cannizzaro (ed), The European Union as an Actor in International Relations (Kluwer, 2002); J. Heliskoski, 'Joint Competence of the European Community and its Member States and the Dispute Settlement Practice of the World Trade Organization' (1999-2000) 2 Cambridge Yearbook of European Legal Studies 80; A. Rosas, 'The European Union and International Dispute Settlement” in L. Boisson de Chazournes, C. Romano and R. Mackenzie (eds.) International Organisations and International Dispute Settlement: Trends and Prospects (Brill, 2002).

31 A. Nollkaemper, Joint Responsibility between the EU and Member States for Non-Performance of Obligations under Multilateral Environmental Agreements' in E. Morgera (ed.) The External Environmental Policy of the European Union: EU and International Perspectives (Cambridge University Press, 2013), at 330.

32 Chapter II DARIO.

33 See e.g., Kuijper and Paasivirta (2013), at 69.

${ }^{34}$ Note, however, that Chapter IV DARIO provides for a number of situations in which the responsibility of an international organization may arise in connection with the act of a State, presumably without attribution, including where the international organization "aids or assist a State in the commission of an internationally wrongful act (Article 14) or "circumvents one of its international obligations" through decisions or authorizations addressed to its members (Article 17), which could arguably be applicable to the EU/MS relationship. However, unlike Articles 6-7 DARIO where responsibility through attribution seems to be a 'blackor-white' question (i.e., either the organization or the State), Chapter IV DARIO appears to create an additional layer of responsibility for the organization without prejudice to that of the State (Article 19), leading therefore to joint responsibility. See further, Hoffmeister (2010), at 727 and Nollkaemper (2013), at 323-324.

35 On this so-called 'executive federalism', see R. Schütze, 'From Rome to Lisbon: 'Executive Federalism' in the (new) European Union' (2010) 47 Common Market Law Review 1385.

36 Article 291(2) TFEU; see Hoffmeister (2010), at 740. 
law, and thus national authorities are likely to be more visible to third parties as the factual actor of an alleged WTO breach. Customs administration constitutes the most obvious example of this special character of the Union's 'executive federalism': even though this is a core EU exclusive competence, there is no EU customs service but 28 national customs administrations that implement (directly applicable) EU customs legislation.

As the European Commission aptly noted in its comments to the ILC, "[t]he fact that the implementation of [EU] law, even in areas of its exclusive competence, is normally carried out by the member States and their authorities, poses the question as to ... when the [EU] as such is responsible not only for acts committed by its organs, but also for actions of the member States and their authorities." ${ }^{37}$ Yet, it is commonly accepted that Article 7 DARIO does not provide an appropriate basis for attributing acts of the Member States when implementing EU law to the Union: its 'normative control' ${ }^{38}$ over Member States' conduct is generally considered to fall short of the 'effective control' test in that provision. ${ }^{39}$ Alternatively, the EU would need to constantly rely on the exception provided for in Article 9 DARIO so as to 'acknowledge and adopt' conduct of its Member States as its own. ${ }^{40}$

That being so, it is understandable to some extent that the European Commission pressed for a special rule of attribution of internationally wrongful acts during the ILC codification process,${ }^{41}$ which was initially opposed by the Special Rapporteur Gaja and eventually led to the introduction of Article 64 DARIO on lex specialis, leaving open the possibility that the general rules on responsibility may be set aside in the case of the EU and its Member States. ${ }^{42}$ As seen earlier for the question of apportionment, the EU equally considers that attribution of conduct should reflect the internal division of competences. Drawing on its statements in the WTO case EC - Computer Equipment (1998) discussed below, ${ }^{43}$ the Commission posits that acts of Member States' authorities when implementing EU law in a field of EU exclusive (external) competence should be attributed to the Union itself. ${ }^{44}$ According to Hoffmeister, this would logically follow from Article 2(1) TFEU given that, in areas of exclusive EU

${ }^{37}$ DARIO Comments (2004), at 29 (para. 3).

${ }^{38}$ Hoffmeister (2010), at 742, suggests that there are two conditions for determining 'normative control' of the Union for the purpose of international responsibility: (i) EU law governs the substantive legality of Member State action; (ii) this is ultimately controlled by the EU judiciary. This approach is borrowed by Kuijper and Paasivirta (2013), at 55; and Nollkaemper (2013), at 335.

39 ILC, 'Draft Articles on the Responsibility of International Organisations, with Commentaries' (2011), Commentary to Article 7, reflecting it was mainly intended to codify rules on the responsibility of international organizations for military operations using forces of its members. See also, Hoffmeister (2010), at 726-727; Nollkaemper (2013), at 331. Kuijper and Paasivirta (2005), at 192, are further critical of the suggestion that, in cases where Member States' authorities implement EU law, such organs are 'placed at the disposal' of the EU: this "grates the ears of the average [EU] lawyer, since it is inherent in the [EU] legal order, and in particular in the primacy of [EU] law, that Member States' legislative, administrative and judicial organs carry out and implement [EU] law."

40 Article 9 DARIO provides: "Conduct which is not attributable to an international organization under articles 6 to 8 shall nevertheless be considered an act of that organization under international law if and to the extent that the organization acknowledges and adopts the conduct in question as its own." For a criticism, see Paasivirta and P.J. Kuijper (2005), at 217.

${ }^{41}$ For a more detailed account, see Hoffmeister (2010), at 728-729.

42 Article 64 DARIO provides: "These draft articles do not apply where and to the extent that the conditions for the existence of an internationally wrongful act or the content or implementation of the international responsibility of an international organization ... are governed by special rules of international law. Such special rules of international law may be contained in the rules of the organization applicable to the relations between an international organization and its members." (emphasis added). The commentary thereto explicitly records that there is a variety of opinions concerning the possible existence of a special rule with respect to the attribution to the EU of conduct of the Member States when they implement binding acts of the Union. For a more detailed account, see Hoffmeister (2010), at 728-729.

43 See section 3.2 below for further discussion.

44 DARIO Comments (2004), at 29 (para. 5). 
(external) competence such as the CCP, "only the Union may legislate and adopt legally binding acts, the Member States being able to do so themselves only if so empowered by the Union or for the implementation of Union acts." ${ }^{45}$ Indeed, a number of scholars have suggested that, if necessary, Article 64 DARIO should be invoked to defend this competencebased approach to attribution and international responsibility. ${ }^{46}$

The problem of attribution of Member States' conduct to the Union should be further refined, though. In support of its position, the Commission often relies on the example of customs legislation, which is a purely external matter and extensively harmonised though EU Regulations that are binding in their entirety and directly applicable in the Member States. ${ }^{47}$ Put differently, EU customs legislation clearly orders what the Member States have to do and they have no choice but to implement it. In these particular circumstances where Member States' conduct is strictly confined to implementing EU law, it is not difficult to accept that national customs authorities act de facto as organs of the Union. Yet, this perfect example of EU executive federalism is not necessarily applicable to all areas covered by WTO law. Part of the reason for this is that the exclusive EU external competence under the CCP is not fully matched by an exclusive competence to regulate internally. As Eeckhout rightly suggests, the taxation of products provides a case in point: externally, such taxation is subject to Article III GATT falling under exclusive EU external competence, whereas internally Member States retain competence for certain forms of taxation that are not harmonised or even regulated at EU level. ${ }^{48}$ When Member States impose such taxes through independent national legislation, can they still be regarded as functionally acting as organs of the Union?

Similar doubts may arise in other 'grey areas' where, even though Member States do act within the scope of EU law, the degree of the Union's normative control over their conduct is more limited than in the context of implementing EU Regulations. One example is State aid, which is subject to WTO disciplines on subsidies: unlike 'classical' executive federalism, EU Member States are not here acting to execute a certain harmonised EU rule, but rather individually providing aid within certain boundaries set by EU law. ${ }^{49}$ In addition, the link between Member States' conduct and EU law may not always be straightforward when they act to implement EU Directives, as these are only binding with respect to the aim(s) pursued but leave some discretion as to the form and method of implementation, ${ }^{50}$ and thus a varied application is likely to result across EU Member States. Moreover, particularly in the fields of consumer and environmental protection, it is not uncommon for the EU to adopt so-called minimum harmonisation Directives setting out standards that national legislations must meet but may exceed if a given Member State so desires: ${ }^{51}$ one significant example in light of the on-going WTO dispute Australia - Tobacco Plain Packaging ${ }^{52}$ are the UK and Irish (draft)

\footnotetext{
45 Articles 2(1) and 3(1)(e) TFEU; Hoffmeister (2010), at 743.

${ }^{46}$ Kuijper and E. Paasivirta (2013), at 69; and Hoffmeister (2010), at 745-746.

47 Article 288 TFEU.

${ }^{48}$ Eeckhout (2006), at 10.

49 Articles 107 (2) and (3) TFEU stipulate the conditions under which State aid, otherwise prohibited under Article 107(1) TFEU, may be considered "compatible with the internal market". Article 108 TFEU empowers the Commission to assess and control the compatibility of State aid granted by the Member States with the internal market. In particular, Article 108(3) TFEU requires Member States, as a general rule, to notify new State aid measures to the Commission and they may only put these measures into effect after obtaining the Commission's approval. However, there are some exceptions to this requirement of prior notification/approval (e.g., State aid covered by the so-called 'Block Exemption' Regulations and de minimis aid). For an overview, see P. Craig and G. de Bùrca, EU Law: Text, Cases and Materials (Oxford University Press, $5^{\text {th }}$ edition, 2011), 10871106.

50 Article 288 TFEU.

51 This is in line with Articles 169(4) and 193 TFEU.

52 Australia - Certain Measures Concerning Trademarks, Geographical Indications and Other Plain Packaging Requirements
} 
legislations on standardised packaging of tobacco products, ${ }^{53}$ which go beyond the requirements of the EU Tobacco Products Directive. ${ }^{54}$ The question thus arises as to whether such a restricted EU normative authority over Member States' conduct may be enough to attribute it to the Union for the purposes of international responsibility. ${ }^{55}$

Against this background, the next section turns to analyse how the WTO dispute settlement has tackled the joint membership of the EU and its Member States. To what extent have these theoretical questions of responsibility been a controversial issue in practice? Or conversely, have third parties in the W'TO de facto accepted the EU's assertion of exclusive responsibility for breaches of WTO law, even by its Member States?

\section{3) EU/MS INTERNATIONAL RESPONSIBILITY IN THE WTO - A CONTROVERSIAL ISSUE IN PRACTICE?}

\subsection{The Broad Picture}

As reflected in Table 1 below, the 'mixed' EU/MS membership of the WTO has been hardly visible in dispute settlement practice.

Table 1 - EU/MS Practice in WTO Dispute Settlement (1995 - 2015)

\begin{tabular}{|l|r|r|r|r|}
\hline & Complainant & Respondent & \multicolumn{1}{|c|}{ Third Party } & \multicolumn{2}{|c|}{ Total } \\
\hline $\begin{array}{l}\text { EU } \\
\text { (individual claims) }\end{array}$ & 95 & $68^{56}$ & 149 & 312 \\
\hline $\begin{array}{l}\text { EU/MS } \\
\text { (joint/parallel claims) }\end{array}$ & - & $14^{57}$ & - & 14 \\
\hline
\end{tabular}

Applicable to Tobacco Products and Packaging, Procedural Arrangement between Australia and Ukraine, Honduras, the Dominican Republic, Cuba and Indonesia, WT/DS434/12, WT/DS435/17, WT/DS441/16, WT/DS458/15, WT/DS467/16, dated 28 April 2014.

53 WTO Committee on Technical Barriers to Trade, 'Notification by the United Kingdom' (G/TBT/N/GBR/24) dated 3 September 2014; 'Notification by Ireland' (G/TBT/N/IRL/1) dated 17 June 2014.

${ }^{54}$ Directive 2014/40/EU of the European Parliament and of the Council on the approximation of the laws, regulations and administrative provisions of the Member States concerning the manufacture, presentation and sale of tobacco and related products and repealing Directive 2001/37/EC [2014] L127/1. Article 24(2) specifically allows that Member States may introduce further requirements in relation to the standardisation of the packaging of tobacco products, provided they are justified on grounds of public health, are proportionate and are not a means of arbitrary discrimination or disguised restriction on trade between Member States.

55 This seems to be the position taken by Hoffmeister (2010), at 746, suggesting the following special rule of attribution: "The conduct of a State that executes the law or acts under the normative control of a regional economic integration organization may be considered an act of that organization under international law, taking account of the nature of the organization's external competence and its international obligations in the field where the conduct occurred." (emphasis added).

56 This number seeks to capture the number of WTO disputes in which the EU sole responsibility was invoked by the third parties concerned. It thus reflects the total 'request for consultations' (i.e., this being the first step in WTO dispute settlement procedures; Article 4 DSU) addressed exclusively to the EU. Note, however, that in some of these cases, a 'mutually agreed solution' was reached by parties to the dispute, while a considerable number of other cases have been formally pending for years at consultations stage.

${ }^{57}$ This number seeks to capture the number of WTO disputes in which the 'joint' responsibility of the EU and its Member States was invoked by the third parties concerned. It thus reflects the total 'request for consultations' addressed to the EU jointly with one or more of its Member States (e.g., WT/DS375-377, European Communities and its Member States - Tariff Treatment of Certain Information Technology Products), and those addressed to the EU in parallel to claims on the same subject-matter addressed to MS (e.g., WT/DS62, EC - Customs Classification of Computer Equipment, in which the US also brought separate claims against Ireland (WT/DS68) and the UK (WT/DS67)). 


\begin{tabular}{|l|r|r|r|r|}
\hline $\begin{array}{l}\text { MS } \\
\text { (individual claims) }\end{array}$ & $1^{58}$ & $10^{59}$ & - & 11 \\
\hline
\end{tabular}

At a first glance, the EU undoubtedly stands out as one of the most active users of the WTO dispute settlement system: out of the total 496 disputes that have been brought for resolution to the WTO since $1995,{ }^{60}$ the Union (alone) has participated either as a complainant (95), a respondent (68) or third party (149) in 312 of them. By way of comparison, the United States (US), as the other key player in the WTO dispute settlement system, has participated in a total of 354 WTO cases ${ }^{61}$ In contrast, the EU Member States (individually) have played a minimal and passive role in WTO dispute settlement: ${ }^{62}$ to date, none has initiated a dispute against a third country ${ }^{63}$ or intervened as a third party in any WTO case, while only some have been occasionally targeted as individual respondents by another WTO member (i.e., the US in all 10 cases) ${ }^{64}$

However, for the purpose of our discussion, it appears pertinent to examine more in depth the statistics concerning passive litigation -i.e., EU/MS acting as a respondent jointly or individually - as an indicator of how the question of EU/MS international responsibility has been approached by third parties and dispute settlement organs in the WTO. In doing so, it seems also interesting to break down such statistics into the pre-Lisbon and post-Lisbon period $^{65}$ as a means to gauging whether, and if so how, the internal transfer of exclusive

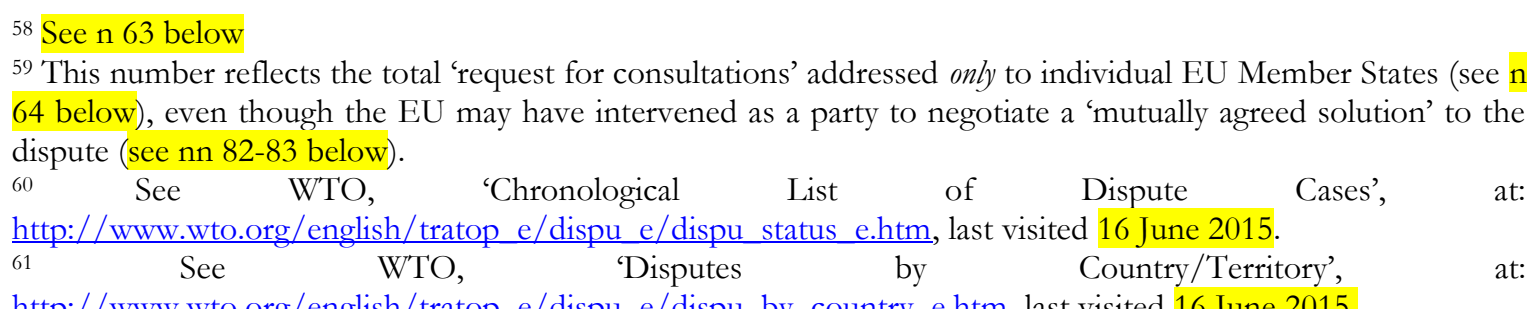
http://www.wto.org/english/tratop_e/dispu e/dispu by country e.htm, last visited 16 June 2015.

62 The lack of active litigation by EU Member States in the WTO dispute settlement system may be due to purely political/institutional reasons, but may also be explained by legal constraints resulting from EU law, and in particular the duty of cooperation (Article 4(3) TEU): for a discussion, see Delgado Casteleiro and Larik (2013), at 242 and 251-252.

${ }^{63}$ To date, the only EU Member State to have initiated WTO dispute settlement procedures is Denmark, but in respect of the Faroe Island and against the EU: European Union-Measures on Atlanto-Scandian Herring, Request for Consultations by Denmark in respect of the Faroe Island, WT/DS469/1, dated 7 November 2013. On 21 August 2014, the parties informed the Dispute Settlement Body that the matter raised in this dispute was settled: European Union - Measures on Atlanto-Scandian Herring, Joint Communication from Denmark in respect of the Faroe Island and the European Union, WT/DS469/3, dated 25 August 2014.

${ }^{64}$ Namely: Belgium (Belgium - Measures Affecting Commercial Telephone Directory Services, Request for Consultations by the United States, WT/DS80/1, dated 13 May 1997; Belgium - Certain Income Tax Measures Constituting Subsidies, Request for Consultations by the United States, WT/DS127/1, dated 11 May 1998; Belgium Administration of Measures Establishing Customs Duties for Rice, Request for Consultations by the United States, WT/DS210/1, dated 19 October 2000); Denmark (Denmark - Measures Affecting the Enforcement of Intellectual Property Rights, Request for Consultations by the United States, WT/DS83/1, 21 May 1997); France (France Certain Income Tax Measures Constituting Subsidies, Request for Consultations by the United States, WT/DS131/1, dated 11 May 1998); Greece (Greece — Certain Income Tax Measures Constituting Subsidies, Request for Consultations by the United States, WT/DS129/1, dated 11 May 1998); Ireland (Ireland - Certain Income Tax Measures Constituting Subsidies, Request for Consultations by the United States, WT/DS130/1, dated 11 May 1998); Netherlands (Netherlands — Certain Income Tax Measures Constituting Subsidies, Request for Consultations, WT/DS128/1, dated 11 May 1998); Portugal (Portugal - Patent Protection under the Industrial Property, Request for Consultations by the United States, WT/DS37/1, dated 6 May 1996) Sweden (Sweden - Measures Affecting the Enforcement of Intellectual Property Rights, Request for Consultations by the United States, WT/DS86/1, dated 2 June 1997).

65 The Treaty of Lisbon was signed on 13 December 2007 and entered into force on 1 December 2009. Thus, in Table 2, 'pre-Lisbon' period refers to all WTO disputes initiated between 1 January 1995 and 1 January 2008, whereas 'post-Lisbon period' to those initiated between 1 January 2008 and 1 March 2015. The underlying 
competence to the EU for all CCP matters has affected the approach to EU/MS international responsibility in the practice of WTO dispute settlement.

\subsection{Pre-Lisbon Practice - Pragmatic Approach to EU (exclusive) Responsibility}

A glimpse at Table 2 below would seem to support the view that, "[i]n fact, the whole discussion on the [joint responsibility] of the EU and its Member States in the WTO is put aside in favour of the sole responsibility of the Union in the WTO dispute settlement system", particularly during the pre-Lisbon period.

Table 2 - EU/MS as Respondents in WTO Dispute Settlement (1995 - 2015)

\begin{tabular}{|l|l|l|}
\hline & Respondent Pre-Lisbon & Respondent Post-Lisbon \\
\hline EU (individual claims) & 54 & 14 \\
\hline $\begin{array}{l}\text { EU/MS } \\
\text { (joint/separate claims) }\end{array}$ & 5 & 9 \\
\hline MS (individual claims) & 10 & 0 \\
\hline
\end{tabular}

Evidently, the vast majority of WTO disputes (54) during the pre-Lisbon period were brought against the EU alone. In all instances, the Union (through the European Commission) has been eager to come forward as lead litigant and to assume exclusive responsibility for all alleged breaches of WTO law, including in the field of the TRIPS agreement that still fell within EU/MS shared competence at that time. ${ }^{67}$ Yet, one should not be bewildered by this wide targeting of the EU as single respondent, given that most of these complaints concerned only legal acts of the EU institutions, ${ }^{68}$ which are clearly attributable to the Union pursuant to

assumption made here is that, in these latter cases, the Lisbon-based change in the internal division of EU/MS external competences for trade matters could have influenced the approach to international responsibility at the consultations stage or/and in Panel/Appellate Body proceedings.

${ }^{66}$ Delgado Casteleiro and Larik (2013), at 238.

${ }^{67}$ Notably: European Communities - Protection of Trademarks and Geographical Indications for Agricultural Products and Foodstuffs, Report of the Panel, WT/DS174/R, adopted 20 April 2005, paras. 7.97-7.98 and 7.722-7.727, involving TRIPS claims against Council Regulation (EEC) No 2081/92 and related implementing and enforcement measures, and where the Panel accepted the EU's explanation of "what amounts to its sui generis domestic constitutional arrangements that [EU] laws are generally not executed through authorities at [EU] level but rather through recourse to the authorities of its Member States which, in such a situation, act as de facto organs of the $[\mathrm{EU}]$ for which the EU would be responsible under WTO law and international law in general." This allowed the Panel to refute the US allegation that there was an infringement of the most-favoured-nation treatment obligation in Article 4 TRIPS, when EU Member States are executing the Union-wide system on the protection of geographical indications as established by the challenged EU Regulation. However, this case did not directly address the question of EU/MS international responsibility, as the US raised violation claims against the EU only, and no specific measure by the EU Member States was identified.

${ }^{68}$ With the exception of the following disputes: European Communities - Trade Description of Scallops, Notification of Mutually Agreed Solution from Canada and the European Union, WT/DS7/12, dated 19 July 1996 and European Communities - Trade Description of Scallops, Notification of Mutually Agreed Solution from Peru, Chile the European Union, WT/DS12/12, WT/DS14/11, dated 19 July 1996, concerning a French Order on the official names and permitted trade descriptions of scallops in France; European Communities - Measures Affecting Butter Products, Notification of a Mutually Agreed Solution from New Zealand and the European Union, W'T/DS72/7, dated 18 November 1999, concerning decisions by the European Commission and the United Kingdom's Customs and Excise Department excluding certain types of New Zealand's butter from eligibility for its country-specific tariff quota established in the EU's Schedule; European Communities - Certain Measures Probibiting the Importation and Marketing of Seal Products, Communication from Canada, WT/DS369/3, dated 3 December 2014, concerning certain measures taken by Belgium and the Netherlands regarding the importation, transportation, manufacturing, marketing and sale of seal products and withdrawn following repeal of such measures. In addition, see cases discussed (n 70, 73 and 74 below). 
Article 6(1) DARIO. ${ }^{69}$ Nonetheless, in some cases, claims directed against the EU alone have involved also measures of its Member States, not only when implementing EU law sensu stricto, but when acting under the normative umbrella of the EU in a broader sense. A well-known example is the EC - Biotech Products (2006) dispute, where the contested measures included national safeguard measures prohibiting the import and/or marketing of specific biotech products, which had been taken by six Member States in reliance on the possibility provided for in the relevant EU legislation. ${ }^{70}$ Even if the degree of EU normative control in respect of these safeguard measures was somehow restricted (i.e., to authorisation), ${ }^{71}$ the WTO panel accepted the EU standing as single respondent and bearing sole responsibility for these measures, based on two 'pragmatic' considerations:

"It is important to note that even though the member State safeguard measures were introduced by the relevant member States and are applicable only in the territory of the member States concerned, the $[\mathrm{EU}]$ as a whole is the responding party in respect of the member State safeguard measures. This is a direct consequence of the fact that the Complaining Parties have directed their complaints against the [EU], and not individual [EU] member States. The [EU] never contested that, for the purposes of this dispute, the challenged member State measures are attributable to it under international law and hence can be considered [EU] measures ..."

In support of this pragmatic approach, the Panel referred to the earlier EC - Asbestos (2001) case, where the EU was targeted as sole defendant -and potentially sole responsible if a breach of the WTO law had been established (quod non)- of the challenged French decree banning asbestos and asbestos-containing products, even though the link between this national measure and EU legislation was not readily obvious. ${ }^{73}$ Another less cited but also important case is EC-Commercial Vessels (2005) concerning the 'grey area' of state aid. Here, the challenged measures included national aid schemes adopted by five EU Member States pursuant to an EU Regulation (providing for a temporary defensive mechanism for the

${ }^{69}$ It suffice to cite the well-known WT/DS26 and WT/DS48 European Communities - Measures Concerning Meat and Meat Products (Hormones) involving (inter alia) claims under GATT, SPS, TBT against Council Directive (EEC) No 602/81, Council Directive (EEC) No 146/88 and Council Directive (EEC) No 299/88; WT/DS27 European Communities - Regime for the Importation, Sale and Distribution of Bananas, involving (inter alia) claims under the GATT, GATS and Import Licensing Agreement against Council Regulation (EEC) No 404/93; WT/DS265, W'T/DS266 and WT/283 European Communities - Export Subsidies on Sugar, involving claims under the Agriculture and SCM Agreements against Council Regulation (EC) No 1260/2001 and related measures; as well as various WTO cases concerning EU trade defence measures (e.g., WT/DS141 European Communities - AntiDumping Duties on Imports of Cotton-type Bed Linen from India, involving claims under the Anti-Dumping Agreement; and WT/DS326 and WT/DS328 European Communities - Definitive Safeguard Measures on Salmon, involving claims under the Agreement on Safeguards).

${ }^{70}$ European Communities - Measures Affecting the Approval and Marketing of Biotech Products, Report of the Panel, WT/DS291/DS/292/DS293/R, adopted 21 November 2006 [hereinafter, EC - Biotech Products], paras. 2.1-2.5.

${ }^{71}$ See Article 23 of Directive (EC) No 2001/18 and Article 12 of Regulation (EC) No 258/97 permitting, under certain conditions, EU Member States to adopt safeguard measures in respect of biotech products that have obtained approval for EU-wide marketing. In such cases, the Member State concerned must inform other EU Member States and the Commission of the action it has taken and a decision on the safeguard measure must then be taken at EU level within a prescribed time period. However, it has been reported that the safeguard measures at issue in this dispute had not been approved by the EU, nor had the European Commission open infringement procedures against the Member States concerned, which in practice were arguably free from EU's normative control: see, A. Delgado Casteleiro, The International Responsibility of the European Union: From Competence to Normative Control (PhD thesis, European University Institute, 2011), at 200.

72 Panel Report in EC - Biotech Products (2006), para. 7.101 (emphasis added).

${ }^{73}$ European Communities - Measures Affecting Asbestos and Products Containing Asbestos, Report of the Panel, WT/DS/135/R, adopted (as modified) 5 April 2001 [hereinafter, EC - Asbestos], paras. 3.32-3.35. While the EU had adopted a series of Directives on the matter since 1980, it was only in May 1999 (i.e., 3 years after the adoption of the French decree) that it decided to introduce an EU-wide ban on all types asbestos (including chrysotile asbestos at issue) with effect from 1 January 2005. 
shipbuilding sector), which had been explicitly authorised by the European Commission. ${ }^{74}$ After formally noting that Korea had made the panel request with respect to the European Union only, ${ }^{75}$ the Panel accepted the EU's sole responsibility for the national aid schemes, emphasising two key elements: (i) the EU Regulation and Commission's decisions were the "legal authority" under which EU Member States provided aid; and (ii) in the event of a finding of WTO-inconsistency, the EU had declared to assume responsibility for "any actions that may be required to bring into conformity the measures at issue", removing thereby the "legal basis for granting any further aid". ${ }^{76}$

Turning to the ten WTO disputes against individual Member States, these were all brought (perhaps non-coincidentally) by the United States and date back to the early years of the WTO dispute settlement system (1995-2000). Some of these cases concerned claims under the GATS and TRIPS, and to some extent may be genuinely motivated by the lack of legal clarity, which prevailed at that time following Opinion 1/94, as to the exact division of competences - and thus, respective obligations- between the EU and its Member States in these fields of WTO law. ${ }^{77}$ However, others involved claims in areas that were unequivocally held in Opinion 1/94 to fully fall under EU exclusive external competence (i.e., the GATT and the SCM Agreement), ${ }^{78}$ and may well have been motivated by a strategic attempt to weaken European unity and leadership in the WTO. ${ }^{79}$ In any event, no WTO panel has pronounced itself on the responsibility of EU Member States in these disputes, as six of them have been formally pending for years at consultations stage, ${ }^{80}$ while in the other four a 'mutually agreed solution' was reached. Nevertheless, it is significant that in all but one ${ }^{81}$ of the cases resulting in a 'mutually agreed solution', this was achieved with the EU intervening as a negotiating/responding party, not only for matters falling under its exclusive external

\footnotetext{
${ }^{74}$ European Communities - Measures Affecting Trade in Commercial Vessels, Report of the Panel, WT/DS301/R, adopted 20 June 2005 [hereinafter, EC - Commercial Vessels], paras. 7.36 - 7.51. The five EU Member States concerned were Denmark, Germany, France, the Netherlands and Spain.

${ }^{75}$ Ibid., para. 7.33.

${ }^{76}$ Ibid., paras. 7.33 and 7.53, and footnote 156. The Panel found that, "[i]n light of these elements, we would find it sufficient, in the circumstances of this case, to address our recommendation to bring the measures at issue into conformity to the [EU]."

${ }^{77}$ With regards to GATS claims, see: Belgium — Measures Affecting Commercial Telephone Directory Services, Request for Consultations by the United States, WT/DS80/1, dated 13 May 1997. As to the TRIPS, see: Denmark Measures Affecting the Enforcement of Intellectual Property Rights, Request for Consultations by the United States, WT/DS83/1, 21 May 1997; Portugal — Patent Protection under the Industrial Property, Request for Consultations by the United States, WT/DS37/1, dated 6 May 1996; Sweden - Measures Affecting the Enforcement of Intellectual Property Rights, Request for Consultations by the United States, WT/DS86/1, dated 2 June 1997.

${ }^{78}$ With respect to the GATT, see: Belgium - Administration of Measures Establishing Customs Duties for Rice, Request for Consultations by the United States, WT/DS210/1, dated 19 October 2000; With respect to the SCM Agreement, see: Belgium - Certain Income Tax Measures Constituting Subsidies, Request for Consultations by the United States, WT/DS127/1, dated 11 May 1998; France - Certain Income Tax Measures Constituting Subsidies, Request for Consultations by the United States, WT/DS131/1, dated 11 May 1998; Greece — Certain Income Tax Measures Constituting Subsidies, Request for Consultations by the United States, WT/DS129/1, dated 11 May 1998 ; Ireland - Certain Income Tax Measures Constituting Subsidies, Request for Consultations by the United States, WT/DS130/1, dated 11 May 1998; Netherlands - Certain Income Tax Measures Constituting Subsidies, Request for Consultations, WT/DS128/1, dated 11 May 1998.

${ }^{79}$ On this point, see S. Billiet, 'The EC and WTO Dispute Settlement: Initiation of Trade Disputes by the EC' (2005) 10 European Foreign Affairs Review 197, at 199.

80 This is the case of the five WTO disputes (at $\mathrm{n} 78$ above) concerning claims under the SCM Agreement, as well as that involving GATS claims (at $\mathrm{n} 77$ above).

81 The exception being: Portugal - Patent Protection under the Industrial Property Act, Notification of a MutuallyAgreed Solution from the United States and Portugal, WT/DS37/2, dated 8 October 1996, following a Portuguese Decree Law to conform with the term of patent protection required by the TRIPS Agreement.
} 
competence ${ }^{82}$ but also for issues revolving around the application of the TRIPS agreement where the extent of its competence was not entirely clear in this pre-Lisbon setting. ${ }^{83}$

Most significant for our purposes, only in a few cases (5) have third parties formally invoked the joint responsibility of the EU and its Member States for alleged breaches of WTO law, by targeting them together (1) or by directing parallel claims on the same subject-matter to each of them separately (4). ${ }^{84} E C$ - Computer Equipment $(1998)^{85}$ was the first case in which the joint EU/MS membership of the WTO caused controversy as to who was responsible in panel proceedings. The case concerned the tariff treatment of certain computer equipment, which the US claimed was in breach of the tariff concessions contained in the EU Schedule under Article II:1 GATT. Thus, it typically illustrates the kind of responsibility question that may arise in the context of 'classical' EU executive federalism -i.e., who is responsible for acts of Member States custom authorities in situations where they functionally act as organs of the Union? Unsurprisingly, the EU sought to assert its exclusive responsibility for any GATT infringement, based on its understanding that apportionment of obligations and attribution of conduct in the context of international responsibility should follow the delimitation of competences under EU law. ${ }^{86}$ In particular, the EU stressed that it was an "original member of the WTO in its own right" and that the tariff concessions "were bound in the GATT 1994 $[\ldots]$ exclusively at the level of the [EU] and not at the level of individual member States." ${ }^{\prime 87}$ Positioning itself as the only bearer of the GATT obligations in question, the EU declared its readiness to assume the "entire responsibility for all measures in the area of tariff concessions", ${ }^{88}$ whether the measure complained about had been taken at EU level or at the level of the Member States. Significantly, the Union went further to support its full responsibility by linking the internal division of competences with the question of who can remedy the alleged wrongs: "it was exclusively competent for the subject matter concerned and

\footnotetext{
82 Notably, Belgium - Administration of Measures Establishing Customs Duties for Rice, Request for Consultations by the United States, WT/DS210/6, Notification of a Mutually Agreed Solution from the United States and the European Union, dated 2 January 2002.

${ }^{83}$ Denmark - Measures Affecting the Enforcement of Intellectual Property Rights, Notification of a Mutually Agreed Solution from the United States, the European Union and Denmark, WT/DS83/2, dated 13 June 2001; and Sweden - Measures Affecting the Enforcement of Intellectual Property Rights, Notification of a Mutually Agreed Solution from the United States, the European Union and Sweden, WT/DS86/2, dated 11 December 1998, both following amendments in the respective national laws to provide for provisional measures inaudita altera parte in civil proceedings involving intellectual property rights.

${ }^{84}$ In addition to the EC - Computer Equipment (1998) dispute discussed here, the other three cases in which parallel claims were directed against the EU and its Member States separately have resulted in a 'mutually agreed solution' or been formally pending at consultations stage for years: (i) France - Measures Relating to the Development of a Flight Management System, Request for Consultations by the United States, WT/DS173/1, dated 31 May 1999; and European Communities - Measures Relating to the Development of a Flight Management System, Request for Consultations by the United States, WT/DS172/1, dated 31 May 1999, concerning GATT and SCM claims; (ii) Ireland - Measures Affecting the Grant of Copyright and Neighbouring Rights and European Communities - Measures Affecting the Grant of Copyright and Neighbouring Rights, Notification of Mutually Agreed Solution from United States, the European Union and Ireland, WT/DS82/3, WT/DS115/3, dated 13 September 2002; (iii) Greece Enforcement of Intellectual Property Rights for Motion Pictures and Television Programs and European Communities Enforcement of Intellectual Property Rights for Motion Pictures and Television Programs, Notification of Mutually Agreed Solution from the United States, the European Union and Greece, WT/DS124/2, W'T/DS125/2, dated 26 March 2001.

${ }^{85}$ European Communities - Customs Classification of Certain Computer Equipment, Report of the Panel, WT/DS62/R, WT/DS67/R, WT/DS68/R, adopted (as modified) 22 June 1998 [hereinafter, EC - Computer Equipment).

${ }^{86}$ See section 2 above.

${ }^{87}$ Panel Report in EC - Computer Equipment (1998), para. 4.10.

88 Oral Pleading of the European Communities to the Panel in EC - Computer Equipment (1998), 12 June 1997, para. 6.
} 
thus the only entity in a position to repair the possible breach" 89 -i.e., the only entity capable of ensuring the necessary restitution under WTO dispute settlement rules. ${ }^{90}$

The US, on the other hand, submitted that both the EU and two of its Member States were responsible for the allegedly wrongful tariff treatment, arguing that Ireland and the UK were "independent members" of the WTO and equally bound by the EU Schedule under the GATT. ${ }^{91}$ For the US, the internal transfer of powers for tariff matters from the Member States to the EU was irrelevant externally, and did not result in "fewer rights and obligations being allotted to the Member States" under WTO law. ${ }^{92}$ Furthermore, the US took the view that the conduct of the Irish and UK customs administrations was attributable to those two States, emphasising that they were told during consultations with the EU that it "could not control the classification practices of member State customs authorities." 93 The Panel, however, avoided addressing explicitly the US request to clarify the responsibility of the respective defendants and instead put forward compromise language that could satisfy both parties: "since the [European Union], Ireland and the United Kingdom are all bound by their tariff commitments under Schedule LXXX, our examination will focus, in the first instance, on whether customs authorities in the [European Union], including those located in Ireland and the United Kingdom, have or have not deviated from the obligations assumed under that Schedule." ${ }^{94}$ On the one hand, the formula 'customs authorities in the European Union' could be read as endorsing the EU's proposition that Member States customs authorities act functionally as EU organs when implementing EU law, ${ }^{95}$ and thus responsibility for their conduct should be solely attributed to the EU. ${ }^{96}$ On the other hand, the Panel sided with the US in that the relevant EU Schedule was equally binding on both the EU and its Member States, ${ }^{97}$ presumably implying all bear international responsibility for any breaches thereof, even if this is an area of EU exclusive competence. Nevertheless, the Panel ultimately found that it was the Union alone to have "acted inconsistently with its obligations under Article II GATT" and addressed recommendations to the EU only. ${ }^{98}$

${ }^{89}$ ILC, 'Responsibility of International Organizations: Comments and Observations Received from International Organizations', Sixty-third Session, Doc A/CN.4/637, dated 14 February 2011, at 24 (emphasis added), where the EU clarified that it was not simply adopting Member States conduct as its own (as per Article 9 DARIO).

${ }^{90}$ On this point, see further section 4.1 below.

${ }^{91}$ Panel Report in EC - Computer Equipment (1998), para. 4.13.

92 Ibid., para. 4.14.

${ }^{93}$ Ibid., para. 4.12. Originally, the US tried to establish separate parallel WTO panels against the EU and the two Member States, but an agreement was reached between the parties to have one panel considering all claims (paras 1.1-1.11).

${ }_{94}$ Ibid., para. 8.16 .

95 This federal-type agency argument was further advanced by the EU and accepted by the WTO panel in European Communities - Selected Customs Matters, Report of the Panel, WT/DS315/R, adopted (as modified) 11 December 2006 [EC - Selected Customs Matters], paras. 7547-7553. However, this case touched only indirectly upon the issue of EU/MS international responsibility, given that the US violation claims under Article X:3 GATT were only addressed against the EU, and not against the EU Member States themselves. This can be easily explained by the fact that the US was directly challenging the decentralised nature of the EU's system of customs administration as being contrary to the uniformity and prompt dispute resolution requirements of Article X:3 GATT. Thus, the preliminary issue that was raised was whether the EU was able to discharge its obligations under Article X:3 GATT through the Member States, which the Panel found to be the case.

${ }^{96}$ For a similar view, see Hoffmeister (2010), at 732.

${ }^{97}$ This was also the position of the Panel in EC - Selected Customs Matters (2006), para. 7.548: "it would appear that the $[\mathrm{EU}]$ as well as its constituent member States concurrently bear the obligations contained in the WTO Agreements, including those contained in Article X:3(b) of the GATT 1994." (emphasis added)

${ }^{98}$ Ibid., paras. 9.1-9.2 (emphasis added). The issue of who was the proper respondent on the EU/MS side was not raised again on appeal: see EC - Computer Equipment (1998), Report of the Appellate Body, WT/DS62/AB/R, WT/DS67/AB/R, WT/DS68/AB/R, adopted 22 June 1998, para. 57. 
The other borderline case of this pre-Lisbon ${ }^{99}$ period in which the joint responsibility of the EU/MS was invoked and addressed by a WTO panel was the famous EC and Certain Member States - Large Civil Aircraft (2011), ${ }^{100}$ which was initiated by the United States back in 2004 but this time directing claims against the EU and four of its Member States together (Germany, France, Spain and the UK). The US claimed they had all provided subsidies separately and in parallel to Airbus large civil aircraft ${ }^{101}$ in contravention of "their obligations" under the GATT and SCM Agreement. ${ }^{102}$ Again not surprisingly from an EU law standpoint, the Union requested that the Panel determine, as a preliminary matter, that the EU was the "only proper respondent" in the dispute, stressing that it was not simply "representing" the Member States in the proceedings, but took "full responsibility" for their actions. ${ }^{103}$ However, the EU's argumentation was essentially limited to restating that the alleged GATT/SCM violations related to matters within its exclusive competence and for which it bears sole responsibility in the WTO ${ }^{104}$ with no indication as to how it would ensure compliance with any potentially adverse Panel's recommendations also by its Member States in this specific case.

The Panel rejected the EU request endorsing instead the formal argument advanced by the US that consultations and panel requests had been made with respect to the four Member States "in addition" to the EU: "[e]ach of these five is, in its own right, a Member of the WTO, with all the rights and obligations pertaining to such membership, including the obligation to respond to claims made against it by another WTO Member." ${ }^{\text {"105 }}$ For the Panel, the 'rules of the organisation' -i.e., the internal division of powers- were of no relevance for the purpose of apportioning WTO obligations and allocating responsibility for any possible breach thereof between the EU and its Member States. Notably, it reasoned that the fact that the four Member States had chosen not to directly defend their interests in the dispute by making oral and written submissions separate from those of the EU was "a matter entirely within their discretion" and subject to their obligations under EU law, but did "not affect their rights or status as respondent parties" under WTO law. ${ }^{106}$ Taking this position a step forward, it held that: "whatever responsibility the [EU] bears for the actions of its member States does not diminish their rights and obligations as WTO Members, but is rather an internal matter concerning the relations between the [EU] and its member States." ${ }^{107}$ Following this line of reasoning, the Panel determined that both the EU and the four Member States had acted

\footnotetext{
${ }^{99}$ While the case was initiated in 2004, Panel and Appellate Body proceedings were only concluded in 2011.

${ }^{100}$ European Communities - Measures Affecting Trade in Large Civil Aircraft, Report of the Panel, Report of the Panel, WT/DS316/R, adopted (as modified) 1 June 2011 [hereinafter, EC - Large Civil Aircraft.

101 The principal measure at issue were the so-called "Launch Aid" or "Member State Financing" (LA/MFS) arrangements, provided by France, Germany, Spain, and the United Kingdom to Airbus for the development of large civil aircraft (LCA). Other measures challenged were: (i) Loans provided through the European Investment Bank to Airbus for LCA design, development, and other purposes; (iii) infrastructure and infrastructure-related grants to Airbus provided by Member State authorities; (iv) the provision to Airbus of equity infusions, debt forgiveness, and grants through government-owned and government-controlled banks; (v) research and technological research funding to Airbus provided by the EU and the Member States.

102 European Communities - Measures Affecting Trade in Large Civil Aircraft, Request for Consultations by the United States, WT/DS316/1, dated 12 October 2004.

103 Panel Report in EC - Large Civil Aircraft (2011), paras. 7.171, requesting that the term "certain Member States" be dropped from the name of the case.

${ }^{104}$ Ibid., para. 7.169 and 7.172. See also, European Communities - Measures Affecting Trade in Large Civil Aircraft, First Written Submission by the European Communities, WT/DS316, dated 9 February 2007, p. 4 and 43 , available at: http://trade.ec.europa.eu/wtodispute/show.cfm?id=268\&code=2\# eu-submissions.

105 Ibid., para. 7.174.

106 Ibid., para. 7.176.

107 Ibid., para. 7.175.
} 
inconsistently with their WTO obligations and addressed recommendations accordingly -i.e., significantly, the first and only WTO ruling to date establishing such a joint responsibility. ${ }^{108}$

\subsection{Post-Lisbon Practice - Challenging EU 'exclusive' Responsibility?}

Against the backdrop of the pre-Lisbon practice just examined, it is readily apparent from Table 2 that joint EU/MS membership of the WTO is becoming much more visible in dispute settlement practice post-Lisbon -even if this may be somehow counterintuitive from an EU law perspective with the Union having been granted exclusive external competence for all CCP matters. At the outset, two main observations can be made: first, complaints addressed jointly to the EU and one or more of its Member States (9) are no longer the exception but almost as common as complaints directed against the EU alone (14); and second, it is no longer just the US bringing such joint complaints, but also other active players in the WTO dispute settlement system (i.e., Argentina, Brazil, China, India, Japan and Russia). Out of the nine cases in which the joint responsibility of the EU and its Member States has been formally invoked, only one ${ }^{109}$ has led to the adoption of a WTO panel report, while the others appear still at consultations/panel request stage. ${ }^{110}$ Therefore, it is too early to appraise the significance of this trend in WTO dispute settlement practice. Nonetheless, it is interesting to note that these cases concern claims under WTO covered agreements falling within the 'old' (e.g., GATT, TBT, SCM Agreements) and 'new' EU exclusive external

\footnotetext{
108 Ibid., para. 8.5. Note, however, that the European Union did not appeal the specific issue of the proper respondent, and thus the Appellate Body did not have a chance to rule on it in an authoritative manner: see, European Communities - Measures Affecting Trade in Large Civil Aircraft, Notification of Appeal by the European Union, WT/DS316/12, dated 23 July 2010. Ultimately, the Appellate Body addressed its recommendations to the EU only: "[...] request the European Union to bring its measures, found in this Report, and in the Panel Report as modified by this Report, to be inconsistent with the SCM Agreement, into conformity with its obligations under that Agreement." (emphasis added). However, it also upheld the Panel's recommendations to "the Member granting each subsidy" for those findings that were not appealed. See EC - Large Civil Aircraft (2011), Report of the Appellate Body, WT/DS316/AB/R, adopted 1 June 2011, paras. 1416 and 1418.

${ }^{109}$ European Communities and its Member States - Tariff Treatment of Certain Information Technology Products, Report of the Panel, WT/DS375/R, WT/DS376/R, WT/DS377/R, adopted on 21 September 2010 [hereinafter, EC - IT Products].

${ }^{110}$ European Union and a Member State - Seizure of Generic Drugs in Transit, Requests for Consultations by India, W'T/DS408/1, dated 19 May 2010; and European Union and a Member State - Seizure of Generic Drugs in Transit, Request for Consultations by Brazil, WT/DS409/1, dated 19 May 2010, both concerning GATT and TRIPS claims against several EU regulations and Dutch measures for the seizure of consignments of generic drugs originating in India by customs authorities in the Netherlands for alleged infringement of patents while in transit to third-country destinations; European Union and a Member State - Certain Measures Concerning the Importation of Biodiesels, Request for the Establishment of a Panel by Argentina, WT/DS443/5, dated 7 December 2012, involving GATT and TRIMS claims against a Spanish Ministerial Order governing the allocation of biodiesel production volumes for computing compliance with mandatory biofuel targets and supposedly adopted pursuant to Directive (EC) No 2009/28; European Union and Certain Member States — Certain Measures Affecting the Renewable Energy Generation Sector, Request for Consultations by China, WT/DS452/1, dated 7 November 2012, regarding claims under GATT, SCM and TRIMS against Italian and Greek measures supposedly taken pursuant to Directive (EC) No 2009/28, and including domestic content restrictions in feed-in tariff programs; European Union and Certain Member States - Certain Measures on the Importation and Marketing of Biodiesel and Measures Supporting the Biodiesel Industry, Request for Consultations by Argentina, WT/DS459/1, dated 23 May 2013, concerning claims under GATT, TBT, SCM and TRIMs against Directive (EC) No 2009/28 and Directive (EC) No 2009/30 and related measures taken by several Member States, establishing sustainability criteria for biofuels and support schemes for the biodiesel sector; European Union and its Member States - Certain Measures Relating to the Energy Sector, Request for the Establishment of a Panel by Russia, WT/DS476/2, dated 28 May 2015, involving claims under the GATT and GATS against the so-called "Third Energy Package", and in particular Directive (EC) No 2009/73 establishing common rules for the transmission, distribution, supply and storage of natural gas, as well as related EU legal instruments and implementing measures by the Member States.
} 
competence (i.e., GATS and TRIPS) alike, and increasingly involve Member States measures taken in the framework of EU legislation in the field of energy and climate change policies. ${ }^{111}$

At the time of writing, the issue of EU/MS joint responsibility has only been addressed by the WTO panel in the EC - IT Products (2010) dispute concerning the tariff treatment of certain information technology products, which the US, Japan and Chinese Taipei claimed was in breach of the EU's and its Member States' obligations under (inter alia) Articles II:1(a) and II:1(b) GATT as it did not respect their commitments to provide duty-free treatment for these products under the Information Technology Agreement (ITA). ${ }^{112}$ The complainants addressed the consultations and panel requests jointly to the EU and its Member States, on grounds that both the EU and its Member States played a role in the application of the duties concerned. The complainants submitted that, while the Union had promulgated the challenged measures, customs authorities of the Member States, in implementing these EU regulations, issued 'Binding Tariff Information' decisions specifying the customs classification code and applied customs duties to the products at issue. They further argued that the "internal legal relationship" between the EU and its Member States "cannot diminish the rights of other WTO members", including under the DSU to bring claims against the EU Member States as WTO members in their own right. ${ }^{113}$

However, the EU notified the Panel that it would participate as sole respondent in the proceedings and bear sole responsibility for any GATT breach. As in the EC-Computer Equipment (1998) dispute discussed above, the EU's assertion of exclusive responsibility was here supported by a combination of internal and WTO-based legal arguments. As could be expected, the Union reiterated its exclusive competence under EU law for all tariff matters, arguing that the role of national customs authorities was limited to applying measures previously enacted at EU level. But critically, it also stressed that this meant, from a WTO law perspective, that only the EU could take "remedial action" to implement the Panel's recommendations to the extent a GATT violation were determined, and thus "addressing any recommendations to each [EU] Member State would serve no useful purpose." 114 In addition, the Union sought to assure the Panel that the EU Member States would be required, as a matter of EU law, to apply any such implementing measures taken at EU level. ${ }^{115}$ The Panel made its recommendations to the EU only, hiding behind a rather 'formalistic' argument (i.e., an "as such" challenge), but ultimately persuaded that EU sole responsibility will bring a satisfactory settlement of this specific dispute:

${ }^{111}$ For an overview, see T. Perišin, 'Pending EU Disputes in the WTO: Challenges to EU Energy Law and Policy' (2014) 10 Croatian Yearbook of International Law 371. On the EU 'Climate and Energy Package', see inter alia K. Kulovesi, E. Morgera and M. Muñoz, 'Environmental Integration and Multi-Faceted International Dimensions of EU Law: Unpacking the EU's 2009 Climate and Energy Package' (2011) 48 Common Market Law Review 829. On the EU 'Third Energy Package' establishing common rules for an internal market in natural gas and electricity, see inter alia R. Boscheck, 'The EU's Third Internal Energy Market Legislative Package: Victory of Politics over Economic Rationality? (2009) 32(4) World Competition 593; and A. Johnston and G. Block, EU Energy Law (Oxford University Press, 2012).

112 European Communities and its Member States - Tariff Treatment of Certain Information Technology Products, Request for the Establishment of a Panel by the United States, Japan and the Separate Customs Territory of Taiwan, Penghu, Kinmen and Matsu, WT/DS375/8, WT/DS376/8, WT/DS377/6, dated 19 August 2008, which also includes claims under Article X GATT (publication and administration of trade regulations) by the United States and Chinese Taipei with regards to one of the products at issue (set-top boxes which have a communication function).

${ }^{113}$ European Communities and its Member States — Tariff Treatment of Certain Information Technology Products, Report of the Panel, WT/DS375/R, WT/DS376/R, WT/DS377/R, adopted 21 September 2010 [hereinafter, EC - IT Products], para. 7.81.

114 Ibid., para. 7.80.

115 Ibid., para. 7.80. 
"[...] we note that the complainants have framed their claims as challenging the [EU] measures "as such" and have confirmed to the Panel that they are not making claims with respect to specific applications of those measures by national customs authorities of any member States. Under the circumstances, the Panel considers that it is not required to make, and does not make, findings with respect to member States' application of the [EU] measures that were challenged "as such" in this dispute. Moreover, we are of the view that findings with respect to the measures adopted by the $[\mathrm{EU}]$ will provide a positive solution to the dispute."116

\subsection{A nuanced assessment of EU (exclusive) Responsibility}

Two general conclusions can be drawn from the preceding analysis of EU/MS participation in the WTO dispute settlement system. First, theoretical questions such as 'who is responsible for what' arising from the joint EU/MS membership of the WTO have seldom been a controversial issue in dispute settlement practice. In fact, the question of EU/MS responsibility has thus far been litigated and directly addressed only on three occasions in WTO panel proceedings (i.e., EC - Computer Equipment (1998), EC - IT Products (2010) and EC - Large Civil Aircraft (2011)). Second, in these few instances where EU/MS responsibility was contentious, what caused contention was the Union's eagerness to be held responsible in lieu of its Member States, and not them seeking to hide behind each other so as to evade international responsibility altogether. ${ }^{117}$ Put differently, concerns over 'accountability gaps' have not really materialised in EU/MS practice within the WTO dispute settlement system. That being so, in which ways does this contribution seek to offer a more nuanced assessment of the EU's leading role in WTO dispute settlement vis-à-vis that found in the literature?

The first qualification made here concerns the degree to which the EU's assertion of exclusive participation and responsibility has been accepted by other WTO members and scrutinised by WTO dispute settlement organs. In this regard, it has been argued that WTO dispute settlement practice "has gone a long way in the direction of attributing the acts of the Member States to EU, in particular when the Member States implement EU law or when their acts fall within the scope of EU legislation." 118 Such a conclusion would seem premature for a number of reasons. First, as we have seen, out of the total 68 WTO disputes in which the EU was targeted as sole respondent, only a few actually raised this sensitive question of attribution of conduct of the EU Member States to the Union. Since the vast majority of these cases involved complaints against EU measures only -rather than specific applications thereof by the Member States, there was no ambiguity that the Union bore sole responsibility for the alleged WTO-inconsistency of such acts. ${ }^{119}$ Second, there were certainly some instances, particularly in the pre-Lisbon period, in which WTO members could have challenged but instead tacitly accepted EU exclusive responsibility for actions of the Member States taken under its (limited) normative authority -notably, EC - Asbestos (2001), EC Commercial Vessels (2005) and EC - Biotech (2006). And it is also true that WTO panels have refrained from interfering with this course of action insofar as it was acquiesced to by WTO members. In this sense, the approach to EU/MS international responsibility in the WTO has been rightly described as being marked by both assertiveness of the Union and pragmatism of all parties involved. ${ }^{120}$ However, this does not necessarily set a precedent for future

\footnotetext{
${ }^{116}$ Ibid., para. 8.2 (emphasis added).

${ }^{117}$ For a similar view, see Delgado Casteliero and Larik (2013), at 255; Eeckhout (2006), at 7.

118 Kuijper and Paasivirta (2013), at 63; for a similar view, see Hoffmeister (2010), at 734 and 743; and Delgado Casteliero (2011), at 202.

119 See notes 68 and 69 above.

${ }^{120}$ Delgado Casteliero and Larik (2013), at 254; Eeckhout (2006), at 7.
} 
disputes. ${ }^{121}$ Indeed, our examination of post-Lisbon practice reveals that WTO members have increasingly brought joint complaints when challenging measures adopted by the Member States within the normative sphere of EU law, ${ }^{122}$ and it remains to be seen how these claims of joint EU/MS responsibility are dealt with if actually contested in WTO panel proceedings. ${ }^{123}$

The second refinement made here pertains to the degree to which EU competence rules have been considered a relevant criterion for the purpose of allocating EU/MS international responsibility, in the three cases in which this proved a controversial issue before WTO panels. In this regard, it has been rightly noted that the approach of W'TO panels has not been entirely consistent. ${ }^{124}$ Understandingly from an international law perspective, WTO panels have consistently taken the position that internal transfers of powers do not affect the validity of WTO obligations for EU Member States: as full WTO members in their own right, they are bound by the entire WTO Agreement (and its covered agreements), in spite of whatever competence the Union may have for parts thereof as a matter of EU law. ${ }^{125}$ In other words, the 'rules of the organisation' are largely irrelevant for the question of apportioning WTO obligations. Conversely, the available WTO jurisprudence is less clear on the extent to which the 'rules of the organisation' may be relevant to the question of attributing acts of the Member States to the Union. Whereas in cases of classical EU executive federalism (i.e., EC Computer Equipment (1998) and EC - IT Products (2010)) WTO panels have ultimately accepted the Union's sole responsibility for acts of its Member States when implementing EU (customs) legislation found in violation of the GATT, the Panel in EC - Large Civil Aircraft (2011)) drew a line in this regard and held both the EU and its Member States responsible for breaches of the SCM Agreement. These different findings cannot be easily explained in light of the internal allocation of competences, since both the GATT and the SCM Agreement have long been within the exclusive external competence of the Union. Yet, as will be argued next, this case law may appear less inconsistent if viewed from the perspective of a WTO panel and its very purpose in assigning responsibility for an internationally wrongful act in the specific treaty context of the WTO.

\section{4) EU/MS INTERNATIONAL RESPONSIBILITY IN THE WTO - A MODEL, OR A CASE APART?}

\subsection{A 'Competence Model', or a 'Competence/Remedy Model'?}

\footnotetext{
121 This point is further corroborated by the fact that there is no strict rule of stare decisis in WTO dispute settlement according to which previous rulings bind panels in subsequent cases, nor an Appellate Body decision on the matter that could be relied upon by future panels; see P. van den Bossche, The Law and Policy of the World Trade Organization (Cambridge University Press, $3^{\text {rd }}$ edition, 2013), at 51-53.

122 On this point, see further section 4.1 below with specific reference to: European Union and Certain Member States - Certain Measures on the Importation and Marketing of Biodiesel and Measures Supporting the Biodiesel Industry, Request for Consultations by Argentina, WT/DS459/1, dated 23 May 2013.

${ }^{123}$ In this context, note that the Panel in EC - IT Products (2010), para. 8.2, sounded a warning that, if necessary, it would have been prepared to address specific recommendations to the Member States, even if they are merely implementing EU legislation found WTO-inconsistent: "[EU] member states are WTO Members in their own right and ... like all WTO Members, they are bound to act consistently with their WTO obligations. Thus, if one or more $[\mathrm{EU}]$ member States were found to have applied WTO inconsistent measures, be they enacted by the States themselves or by the $[\mathrm{EU}]$, it could be appropriate to find that the member States have acted inconsistently with their WTO obligations." For a similar reading, see L. Bartels, 'Procedural Aspects of Shared Responsibility in the WTO Dispute Settlement System' (2013) 4(2) Journal of International Dispute Settlement 343, at 352.

124 Kuijper and Paasivirta (2013), at 60.

125 Panel Report in EC - Computer Equipment (1998), para. 8.16; Panel Report in EC - IT Products (2010), para. 8.2; Panel Report in EC and Certain Member States - Large Civil Aircraft (2011), para 7.174.
} 
In comparing the different approaches to EU/MS international responsibility in the WTO and under the European Convention on Human Rights, Kuijper aptly qualifies the relative impact of the EU's internal rules on determinations of international responsibility. He argues that it is not just internal factors, such as the scope of EU powers and whether the Member States may be seen as de facto Union organs in certain instances, which determine the degree to which the EU will bear sole or joint responsibility. ${ }^{126}$ Rather, these internal elements "will be strongly vary in impact on the final questions of attribution and responsibility" depending on the specific treaty regime in which the responsibility of the EU and/or its Member States is invoked, and in particular the prevailing remedy for an internationally wrongful act preferred by the regime in question. ${ }^{127}$ In the context of the WTO, both the legal texts and the practice of the dispute settlement organs clearly attach a strong preference for juridical restitution i.e., the 'prompt' withdrawal (or modification) of the WTO-inconsistent measure and continued performance of WTO obligations. ${ }^{128}$ In such a system where the primary consequence of international responsibility is the return to legality, the key question becomes who (i.e., the EU or the Member States, or both) has the actual power to undo the wrongful act and ensure conformity to existing WTO obligations. In this sense, as rightly pointed out by Nollkaemper, the role of power in determining international responsibility (whether joint or not) is a fundamental one. ${ }^{129}$ Put simply, why would WTO dispute settlement organs bother to assign responsibility to a WTO member that does not hold the power to remove (or modify) the measure found WTO-inconsistent?

That being said, does it necessarily follow that the EU is the one and only able to provide for restitution and ensure performance of WTO obligations in all instances? This would seem to be the view taken by Kuijper and Paasivirta in suggesting the so-called 'competence model' for managing EU/MS international responsibility in the WTO. In their opinion, the relevant WTO member is the Union and not the Member States: given the near-exclusive EU external competence for WTO matters post-Lisbon, only its institutions can provide for the necessary restitution and thus the Union should be solely responsible for the WTO-inconsistency of all acts taken in the sphere of EU law, including by its Member States. ${ }^{130}$ But if this proposition is accepted, what would be the legal justification for the Member States to remain independent members of the WTO, given they are claimed entirely incompetent to fulfill one of the key obligations of that membership -i.e., to ensure the conformity of their laws, regulations and administrative procedures with WTO obligations ${ }^{131}$ ?

In reality, the proposed 'competence model' may need some refinement, as evidenced by the EU's own argumentation in the three WTO cases previously discussed in which EU/MS

\footnotetext{
${ }^{126}$ P. J. Kuijper, 'Attribution - Responsibility - Remedy: Some Comments on the EU in Different International Regimes' (2014) SHARES Research Paper 30, at 20.

127 Ibid., at 2.

128 Article 3.7 DSU reads: "[...] In the absence of a mutually agreed solution, the first objective of the dispute settlement mechanism is usually to secure the withdrawal of the measures concerned if these are found to be inconsistent with the provisions of any of the covered agreements [...]" (emphasis added); see also Articles 19.1 and 21.1 DSU; and van den Bossche (2013), at 194-195 for an overview.

${ }^{129}$ Nollkeamper (2013), at 307-308 and 346.

130 This 'competence model' was first introduced in Kuijper and Paasivirta (2013), at 54-55, and further elaborated in Kuijper (2014), at 8-9 and 18. A similar view is taken by Hoffmeister (2010), at 743: "Article 2(1) TEU expresses the rule that Member States can no longer act in such exclusive Union policies unless if so empowered by the Union. Accordingly, Union law contains a strong indication that in areas of exclusive external Union competence action of either the Union institutions or the Member States should be attributed to the Union, as only the Union has the legal power to act in this field and to remedy the potential breach of international law." (emphasis added).

131 See Article XVI:4 WTO Agreement.
} 
responsibility proved contentious in panel proceedings. On the one hand, the two premises underlying the 'competence model' appear perfectly sensible when applied to situations of classical EU executive federalism such as those posed by the EC - Computer Equipment (1998) and EC - IT Products (2010) disputes involving EU customs legislation. In both cases, it was plainly clear that: first, the EU had required the Member States to act inconsistently with WTO law -i.e., by adopting the challenged (directly applicable) regulations that Member States have no choice but to apply and which left no room for discretion in terms of implementation; and second, the EU was the only entity with the actual power to provide restitution -i.e., to modify/withdraw the regulations found WTO-inconsistent. Under these circumstances where the Union has full ex-ante and ex-post normative control over Member State action, it would not be very efficient nor provide much legal certainty from a third-party perspective, to hold EU Member States responsible as they do not have any individual power to undo the wrongful situation and ensure performance of W'TO obligations.

On the other hand, it is less straightforward whether these two assumptions underpinning the 'competence model' can be upheld as we move away from tariffs and customs matters into other areas of WTO law, which are not so extensively regulated at EU level and where the role of the EU Member States is not strictly confined to executing EU law. This point is well illustrated by the EC-Large Civil Aircraft (2011) dispute. First, it is generally the case that, in the field of State aid, the EU does not require but at most authorises Member States to provide aid under certain conditions, ${ }^{132}$ and therefore Member States do enjoy some level of discretion in whether or not they act in contravention of the SCM Agreement. Moreover, in this particular dispute, the EU did not point to any Commission state aid decision actually authorising the separate subsidies granted by the Member States, ${ }^{133}$ and it has indeed been reported that such subsidies were not subject to a specific EU authorisation. ${ }^{134}$ This being so, it would be hard to see how the EU could claim to exercise normative control over Member State subsidising action where there appears to be no basis in EU law for assessing the substantive legality of such action. ${ }^{135}$ Indeed, even in an area where the EU has exclusive competence both externally and internally, ${ }^{136}$ it may be possible for Member States to act outside the scope of EU normative authority in a manner that violates the SCM Agreement: a key reason for this is that the Commission's control powers are limited to government support that constitutes 'State aid', which is a narrower concept than the WTO's notion of 'subsidy. ${ }^{137}$ Second, in terms of remedial action, the EU did not attempt to argue that it was

\footnotetext{
132 See $\mathrm{n} 49$ above.

${ }^{133}$ See e.g., European Communities - Measures Affecting Trade in Large Civil Aircraft, First Written Submission by the European Communities, WT/DS316, dated 9 February 2007, at 89-95 providing the factual background to MSF/LA arrangements.

134 See e.g., Kuijper and Paasivirta (2013), at 63; and Delgado (2011), at 206. In this sense, EC - Large Civil Aircraft (2011) significantly differs from the EC-Commercial Vessels (2005) dispute, where EU law was clearly at the origin of the national aid schemes found WTO-inconsistent and EU sole responsibility was accepted (see section 3.2 above)

${ }^{135}$ Hoffmeister (2010), at 742, stating that it is necessary to establish that EU law governs the substantive legality of Member State action as one of the conditions for determining 'normative control' of the Union for the purpose of international responsibility.

${ }^{136}$ See Article 3(1)(b) TFEU.

${ }^{137}$ Pursuant to Article 107(1) TFEU, four cumulative conditions have to be met for a Member State's measure to be considered 'State aid' and come within the scope of EU rules: (i) there has been an intervention by the State or through State resources; (ii) the intervention gives the recipient an advantage on a selective basis; (iii) competition has been or may be distorted; (iv) the intervention is likely to affect trade between Member States. Whereas (i) and (ii) resemble the WTO criteria of 'financial contribution by a government/public body conferring a benefit' (Annex 1.1) and 'specificity' (Articles 1.2 and 2) for determining the existence of a 'subsidy' under the SCM Agreement, WTO disciplines are clearly not confined to government support measures that distort competition and trade within the EU (i.e., conditions (iii) and (iv) for 'State aid'), but more broadly apply to subsidies that affect international trade (e.g., export and import substitution subsidies prohibited under Article
} 
best placed to implement the Panel's recommendations. In fact, it is far from evident that the Union alone could have remedied the wrongful situation, particularly for those "Member State Financing" (or "Launch Aid") measures that the Panel found to constitute a prohibited (export) subsidy under Article 3.1(a) SCM Agreement and had to be withdrawn within 90 days. ${ }^{138}$ Under these circumstances, it appears perfectly sensible for the Panel to address individual recommendations to each subsidising EU Member State, as they had actual power and full discretion to withdraw their WTO-inconsistent subsidies with no need for any prior EU legislative action.

Therefore, the EC - Large Civil Aircraft (2011) dispute highlights that a perfect match between EU exclusive external competence for WTO matters and exclusive remedial capacity for any breach of WTO law, which underlies the 'competence model', cannot simply be taken for granted. The question remains, however, whether this may be considered a marginal case due to the peculiarities of EU State aid rules, or conversely whether similar doubts as to the EU's exclusive ability to provide restitution could arise in other fields of WTO law. Arguably, this could also become an issue in WTO disputes involving acts of the Member States apparently aimed at implementing EU Directives, where it can be highly complex, particularly for a third party, to identify whether the alleged W'TO-inconsistent measure was required by EU law, or instead results from an autonomous decision of the Member States, or indeed implicates both. ${ }^{139}$

A case in point is the recent complaint brought by Argentina against the EU and some of its Member States regarding certain measures affecting the marketing of biodiesel products and supporting the biodiesel industry. ${ }^{140}$ On the one hand, the EU seems clearly responsible for GATT/TBT claims against the 'sustainability criteria' for biofuels and bioliquids: ${ }^{141}$ these are established as mandatory common standards in the EU Renewable Energy and Fuel Quality Directives $^{142}$-i.e., only conforming biofuels and bioliquids may count towards meeting the

3 SCM Agreement) and cause 'adverse effects' to other WTO members (i.e., so-called 'actionable subsidies' under Article 5 SCM Agreement). For further discussion, in the specific context of the EC-Large Civil Aircraft (2011) dispute, see M. Wu, 'Why not Brussels? European Community State Aid Rules and the Boeing-Airbus Dispute: Comment on Piet Jan Slot' in K. W. Bagwell, G. A. Bermann and P.C. Mavroidis, Law and Economics of Contingent Protection in International Trade (Cambridge University Press, 2010).

138 Panel Report in EC - Large Civil Aircraft (2011), paras. 8.1 and 8.6, pursuant to Article 4.7 SCM Agreement. Note, however, that this finding was reversed by the Appellate Body, as it disagreed with the Panel's standard for determining when a subsidy can be considered as de facto contingent upon anticipated export performance under Article 3.1(a) and footnote 4 SCM Agreement: see AB Report in EC-Large Civil Aircraft (2011), paras. 1415-1416.

${ }^{139}$ See e.g., European Union and Certain Member States - Certain Measures Affecting the Renewable Energy Generation Sector, Request for Consultations by China, WT/DS452/1, dated 7 November 2012, at 1, whereby China challenges the domestic content restrictions in the feed-tariff programmes of Greece and Italy stating that "these measure appear to have been promulgated under the powers delegated to EU Member States by, inter alia, Directive 2009/28/EC ..."

140 European Union and Certain Member States - Certain Measures on the Importation and Marketing of Biodiesel and Measures Supporting the Biodiesel Industry, Request for Consultations by Argentina, WT/DS459/1, dated 23 May 2013.

${ }^{141}$ Ibid., at 1-4. In particular, Argentina objects to the requirement that, in order to be considered 'sustainable', biofuels and bioliquids must save at least 35\% of green house emissions relative to fossil fuels, arguing that this threshold is arbitrary and appears neither to be scientifically proven nor based on any international standard. With regards to these GATT/TBT claims (PART A), Argentina appears indeed to invoke solely EU responsibility, in referring to Article XVI:4 WTO Agreement: “[...] the measures do not appear to conform to the obligation of the European Union to ensure the conformity of its laws, regulations and administrative procedures with the obligations incumbent upon it under the annexed Agreements." (emphasis added). This reference is not made with respect to GATT/SCM claims in Part B of the consultations request (see n144 below).

142 See Directive No 2009/28/EC, Article 17; Directive No 2009/30/EC, Article 7(b). 
obligatory national renewable energy targets set out for each Member States ${ }^{143}$ and/or be eligible for financial support- and therefore only the EU is in a position to modify (or withdraw) these criteria if found WTO-inconsistent. On the other hand, it is less obvious whether the Union is equally responsible for GATT/SCM claims against tax exemptions/reductions on such 'sustainable' biofuels allegedly applied by some EU Member States: ${ }^{144}$ these tax incentives are not, strictly speaking, required by EU law ${ }^{145}$ and therefore Member States retain the power to withdraw them if found WTO-inconsistent. In fact, this case raises the type of responsibility question that was pragmatically avoided in the EC Biotech (2006) dispute discussed above and, should it reach panel proceedings, may provide a first opportunity for WTO dispute settlement organs to actually rule on the question of who is responsible for conduct of the Member States that is authorised in EU Directives. ${ }^{146}$

In addition, one should bear in mind that there is no strict parallelism between EU exclusive external competence in the field of the $\mathrm{CCP}$ and the distribution of internal regulatory competences between the Union and its Member States. ${ }^{147}$ To put it differently, even if it is accepted that the Union has exclusive treaty-making powers for (nearly) all WTO matters, it does not have exclusive treaty-infringing powers. There are some important policy fields covered by WTO law that have been only partially regulated at EU level and where Member States retain considerable regulatory autonomy internally: one example seen earlier is internal taxation (covered by GATT) ${ }^{148}$ and another patent law (covered by TRIPS). ${ }^{149}$ In these areas,

${ }^{143}$ Directive 2009/28/EC, Article 3 and Annex I, sets out legally binding and differentiated targets for each Member States, in order to: (i) increase the share of renewable energy to at least $20 \%$ in EU gross final consumption of energy by 2020; (ii) increase the share of renewable energy to $10 \%$ of energy used in the transport sector in each Member States by 2020. For a discussion, see A. Swinbank, EU Support for Biofuels and Bioenergy, Environmental Sustainability Criteria, and Trade Policy (International Centre for Trade and Sustainable Development, June 2009), available at: http://www.ictsd.org/downloads/2012/02/eu-support-for-biofuelsand-bioenergy-environmental-sustainability-criteria-and-trade-policy.pdf.

144 European Union and Certain Member States - Certain Measures on the Importation and Marketing of Biodiesel and Measures Supporting the Biodiesel Industry, Request for Consultations by Argentina, WT/DS459/1, dated 23 May 2013, at 4-7. The EU Member States concerned are Belgium and France.

145 Directive 2003/96/EC, para. 26 of the Preamble and Article 15 allow Member States to exempt or reduce excise duties so as to promote the use of biofuels. As such tax exemption/reduction may constitute 'State aid', Member States are required (Article 26) to notify such measures to, and obtain approval from, the Commission pursuant to Article 108 TFEU (see n49 above). Implementation of such tax incentive schemes varies significantly across EU Member States: for an overview, see A. Jung et al., Biofuels - At What Cost? Government Support for Ethanol and Biodiesel in the European Union: 2010 Update (International Institute for Sustainable Development, July 2010), at 42-47, available at: https://www.iisd.org/gsi/sites/default/files/bf eunion 2010update.pdf.

${ }^{146}$ See also, European Union and its Member States - Certain Measures Relating to the Energy Sector, Request for the Establishment of a Panel by Russia, WT/DS476/2, dated 28 May 2015, concerning inter alia GATS claims against Directive (EC) No 2009/73 and Member State implementing measures, particularly by Croatia, Hungary and Lithuania. Here, however, the degree of discretion left to the Member States in implementing the EU Directive (i.e., they may select among three alternative 'unbundling' models provided for in Article 9 in ensuring the separation of natural gas production/supply from transmission networks) does not appear to be the only rationale for invoking their responsibility: rather, the alleged claims of violation of Articles XVI and XVII GATS are based on the specific commitments that the three EU Member States concerned (presumably) undertook in their individual Services Schedules (see n 27 above) with respect to pipeline transport services.

147 This is reflected in Article 207(6) TFEU, providing that the exercise of EU exclusive competence in the field of common commercial policy "shall not affect the delimitation of competences between the Union and the Member States, and shall not lead to harmonisation of legislative or regulatory provisions of the Member States in so far as the Treaties exclude such harmonisation."

148 Article 113 TFEU provides the legal basis for the harmonisation of national legislations for certain forms of taxation (e.g., turnover taxes, excise duties and other forms of indirect taxation), but only "to the extent that such harmonisation is necessary to ensure the establishment and the functioning of the internal market and to avoid distortion of competition." On this point, see Eeckhout (2006), at 10. 
it could well be that an act of a EU Member State outside the scope of EU legislation infringes WTO law. If presented with such a scenario, proponents of EU exclusive responsibility may still argue that the Union has internal control mechanisms to effectively ensure compliance with an adverse WTO ruling, ${ }^{150}$ notably by initiating infringement proceedings against the Member State(s) concerned. ${ }^{151}$ However, from the perspective of the WTO dispute settlement organs, why would this be any more effective than holding the infringing EU Member State directly responsible?

To sum up, when approaching EU/MS responsibility for breaches of WTO law, the key practical question is who has the actual power to provide juridical restitution and secure performance of WTO obligations, as underscored by the 'competence/remedy' model suggested here. From this angle, the internal distribution of competences becomes a relevant criterion for the purposes of attributing EU/MS international responsibility: complaining parties would generally address their claims, ${ }^{152}$ and WTO dispute settlement organs their findings, based on their assessment of who is in the best position to withdraw or amend the WTOinconsistent measure. ${ }^{153}$ However, and importantly, it does not follow that the EU -and not its Member States- is the relevant WTO member in each and every case just because it has exclusive external competence for WTO matters. As we have seen, it is not a foregone conclusion that EU Member States have no role to play in ensuring conformity of their laws, regulations and administrative practices with WTO law, and particularly as we move away from highly integrated areas of the CCP. So as long as they remain independent members of the WTO, EU Member States can be targeted as respondents and incur responsibility for their WTO-infringing conduct, particularly where they retain an actual power to undo the wrongful situation -i.e., because EU normative control over their action is either limited or absent altogether. That being so, there appears to be no compelling grounds why WTO dispute settlement organs should instead rely on the Commission's infringement action or other internal enforcement mechanisms so as to ensure due performance by the Member States of their W'TO obligations.

\subsection{A Case Apart?}

The aforementioned 'competence/remedy' model to EU/MS international responsibility in the WTO inevitably raises the question as to whether the internal division of powers between

\footnotetext{
${ }^{149}$ Article 118 TFEU provides the legal basis for the creation of European intellectual property rights and for the setting up of centralised Union-wide authorisation, coordination and supervision arrangements. One of the few pieces of EU legislation in the field of patent law: Directive 98/44/EC of the European Parliament and of the Council of 6 July 1998 on the legal protection of biotechnological inventions [1998] OJ L213/13. For an account of the difficulties in harmonising patent law at the EU level, see chapter by Aurora Plomer in this book. ${ }^{150}$ See Kuijper and Paasivirta (2013), at 39 and 59.

151 Articles 258 and 260 TFEU; and C - 239/03 Commission v France (Étang de Berre) [2004] ECR I-9325, para. 29 (concerning also a 'mixed' agreement). Pursuant to Article 216(2) TFEU, the WTO covered agreements are also binding upon the EU Member States as a matter of EU law, and thus they are under an obligation in EU law to adopt the necessary measures to implement WTO obligations, and refrain from taking any measure that would undermine due performance of such obligations. See generally, M. Mendez, 'The Enforcement of EU Agreements: Bolstering the Effectiveness of Treaty Law?' (2010) 47(6) Common Market Law Review 1719.

${ }^{152}$ However, see Delgado Casteleiro and Larik (2013), at 253 rightly noting that complaining parties in the WTO may strategically target the EU as a respondent, rather than individual Member States, fostered by the prospects of being capable to retaliate (i.e., 'suspension of concessions or other obligations' as one of the temporary remedies provided for in Article 3.7 and 22.2 DSU) against the Union as a whole in their quest to induce compliance. Yet arguably, this possibility of retaliating against the Union as a whole is not impaired by bringing joint complaints again the EU and (some of) its Member States.

153 For a similar view, in the context of non-compliance proceedings under multilateral environmental agreements, see Nollkaemper (2013), at 343 and 346.
} 
the Union and its Member States may matter less for determinations of international responsibility in other treaty regimes which, unlike the WTO dispute settlement system, do not favour juridical restitution as the primary remedy for breaches. This proposition is, indeed, supported by the approach taken to the apportionment of responsibility between the EU and its Member States in the context of Investor-State dispute settlement (ISDS) proceedings, where the most common remedy is monetary compensation. ${ }^{154}$ Thus, in this treaty context, the key question is most often who should pay monetary damages awarded by arbitral tribunals, and not so much who holds the power to undo a wrongful act. ${ }^{155}$ As exposed below, even though foreign direct investment (FDI) is also in an area of exclusive EU external competence, ${ }^{156}$ the Union seems here less eager to assume exclusive responsibility at all costs.

The reasons for this are spelled out in the recently adopted EU Regulation establishing a framework for managing financial responsibility linked to State-investor dispute settlement, ${ }^{157}$ but are somehow contradictory. On the one hand, the Regulation reaffirms the view that international responsibility should follow the internal division of powers: given that the EU is exclusively competent to assume international obligations in the field of FDI, only the EU can in principle act as a respondent and be held internationally responsible for violations of FDI provisions, "irrespective of whether the treatment at issue is afforded by the Union itself or by a Member State." ${ }^{158}$ On the other hand, the Regulation seeks to distinguish between this external responsibility under public international law and the allocation of financial responsibility as an internal EU law matter, decided irrespective of international responsibility:

"Where the Union ... has international responsibility for the treatment afforded, it will be expected, as a matter of international law, to pay any adverse award and bear the costs of any dispute. However, an adverse award may potentially flow either from treatment afforded by the Union itself or from treatment afforded by a Member State. It would as a consequence be inequitable if awards and the costs of arbitration were

\footnotetext{
154 See e.g., R. Dolzer and C. Shreuer, Principles of International Investment Law (OUP, $2^{\text {nd }}$ edition, 2012), at 296-297. 155 While arbitral tribunals do in principle have the power to award restitution (unless excluded in a given investment treaty), it has seldom been requested and awarded in practice. On the reasons for this, see $\mathrm{S}$. Ripinsky and K. Williams, Damages in International Investment Law (British Institute of International and Comparative Law, 2008), at 57-59.

${ }^{156}$ Following the entry into force of the Lisbon treaty, foreign direct investment is now included within the CCP under Article 207(1) TFEU. On this new competence, see inter alia J.A. Bischoff, 'Just a little BIT of "mixity"? The EU's role in the field of international investment protection law' (2011) 48(5) Common Market Law Review 1527; J. Chaisse, 'Promises and Pitfalls of the European Union Policy on Foreign Investment - How Will the New EU Competence on FDI Affect the Emerging Global Regime' (2012) 15(1) Journal of International Economic Law 51; A. Dimopoulos, 'Creating an EU Investment Policy: Challenges for the Post-Lisbon Era of External Relations' in P.J. Cardwell (ed.), EU External Relations Law and Policy in the Post-Lisbon Era (Asser Press, 2012); A.R. Ziegler, 'The New Competence of the European Union in the Area of Foreign Direct Investment (FDI): A Third Country Perspective' in M. Bungenberg and C. Herrmann (eds), European Yearbook of International Economic Law - Common Commercial Policy After Lisbon (Springer, special issue, 2013).

${ }^{157}$ Regulation (EU) No 912/2014 of the European Parliament and of the Council of 23 July 2014 establishing a framework for managing financial responsibility linked to investor-to-state dispute settlement tribunals established by international agreements to which the European Union is party [2014] OJ L257/121 [hereinafter, EU Regulation No 912/2014]. For a more detailed account, see chapter by Catharine Titi in this book.

158 Regulation (EU) No 912/2014, paragraph 3 of the Preamble. See also, European Commission, 'Proposal for a Regulation of the European Parliament and of the Council establishing a framework for managing financial responsibility linked to investor-state dispute settlement tribunals established by international agreements to which the European Union is party' (COM (2012) 335 final), dated 21 June 2012, at 4 stating that: "Should it be the case that both the European Union and the Member States are parties to an agreement and it needs to be decided who is responsible as a matter of international law for any particular action, the Commission takes the view that this has to be decided not by the author of the act, but on the basis of the competence for the subject matter of the international rules in question, as set down in the Treaty. In this perspective, it is immaterial that a Member State has competence under the rules on the internal market allowing it to legislate in its domestic sphere." (emphasis added).
} 
to be paid from the budget of the Union where the treatment was afforded by a Member State, unless the treatment in question is required by Union law. It is therefore necessary that financial responsibility be allocated, as a matter of Union law, between the Union itself and the Member State responsible for the treatment afforded on the basis of criteria established by this Regulation." ${ }^{159}$

It is questionable whether such a distinction is convincing, among others because the EU Regulation directly links the internal allocation of financial responsibility with respondent status in ISDS proceedings. As a general rule, ${ }^{160}$ participation in arbitral proceedings follows the division of financial responsibility, whereby the EU should act as sole respondent where the dispute: (i) involves (exclusively or also) treatment afforded by its institutions; or (ii) involves treatment afforded by the EU Member States insofar as the treatment concerned "is required by Union law". ${ }^{161}$ Unless this is so, EU Member States should act as the respondent in investment disputes concerning treatment afforded by their own organs. ${ }^{162}$ In case of an adverse ruling, EU Member States would not only bear financial responsibility under EU law, but also and importantly under international law -i.e., an international law obligation to pay damages awarded by the arbitral tribunal in question. ${ }^{163}$

It follows therefore that, in the context of ISDS, the Union is only ready to take up international responsibility for acts of its Member States to the extent that such conduct is required by EU law. While this criterion is not crystal-clear and may not always be easy to apply in practice, ${ }^{164}$ 'required by Union law' does narrow the scope of EU sole responsibility for the acts of its Member States in the investment context. Arguably, it does not encompass all instances in which EU Member States act in the execution of EU legislation, but this will depend on the level of discretion left to them in terms of implementation. ${ }^{165}$ In other words,

${ }^{159}$ Regulation (EU) No 912/2014, paragraph 5 of the Preamble.

${ }^{160}$ Regulation (EU) No 912/2014, Article 9 provides exceptions to this general rule, whereby the EU will act as the respondent independently of where financial responsibility lies, notably: (i) where similar treatment is being challenged in a related claim against the Union in the WTO, provided that a WTO panel has been established and the claim concerns the same specific legal issue and it is necessary to ensure consistent argumentation in the WTO (Article 9(3)); and (ii) where EU Member States decline to act as respondents, even though financial responsibility lies with them (Article 9(1)(b)).

${ }_{161}$ Regulation (EU) No 912/2014, paragraphs 7-9 of the Preamble; Article 3(1)(a) and (c); Article 4(1); Article 9 (2).

162 Regulation (EU) No 912/2014, Article 9(1). Therefore, the Regulations seeks to eliminate the possibility of bringing a claim simultaneously against both the EU and the Member States: see further, F. Baetens, G. Kreijen and A. Varga, 'Determining International Responsibility under the New Extra-EU Investment Agreements: What Foreign Investors in the EU Should Know' (2014) 47(5) Vanderbilt Journal of Transnational Law 1203, at 1225-1227. This 'either/or' approach has also been incorporated in the EU-Canada Comprehensive Economic and Trade Agreement, Article X.20, which provides a procedural mechanism for the determination of respondent status in disputes with the EU or its Member States. In essence, the EU is under an obligation to inform the investor concerned as to whether the Union or a Member State shall be the respondent and thus discharge international responsibility. If it fails to do so within 50 days, responsibility will be divided as follows: (i) where the measures identified by the investor are exclusively measures of a Member State, that Member State shall be the respondent; (ii) where the measures identified by the investor include measures of the EU, the Union shall be respondent.

163 A. Dimopoulos, 'The Involvement of the EU in Investor-State Dispute Settlement: A Question of Responsibilities' (2014) 51 Common Market Law Review 1671, at 1677-1678.

${ }^{164}$ See on this point, C. Tiejte, E. Sipiorsk and G. Topfër, Responsibility in Investor - State Arbitration in the EU (European Parliament, 2012), at 18-19, available at:

http://www.europarl.europa.eu/RegData/etudes/etudes/join/2012/457126/EXPO-

INTA ET\%282012\%29457126 EN.pdf.

165 See notably, Regulation (EU) No 912/2014, paragraph 7 of the Preamble, qualifying this criterion in the context of EU Directives: “... where the Member State acts in a manner required by Union law, for example in transposing a directive adopted by the Union, the Union itself should bear financial responsibility in so far as the 
emphasis here is not so much on who is competent for contracting the international investment obligation in question, but rather on whether a provision in EU law is actually at the origin of the breach. Whereas this more cautious approach in asserting EU exclusive responsibility vis-à-vis that taken in the WTO may be explained by moral hazard concerns, ${ }^{166}$ it is nonetheless at odds with the Union's own argument that the scope of EU exclusive external powers should be the decisive factor for assigning EU/MS responsibility under mixed agreements. ${ }^{167}$

\section{5) CONCLUSIONS}

It is largely undisputed that the European Union has played a prominent role in the WTO dispute settlement system over the past two decades. As one of the rare international fora where the EU is actually allowed to fully participate in dispute settlement proceedings, it is not surprising that the Union has been eager to stand as a 'responsible' -if not 'overresponsible'-actor in the multilateral trading system, even if not always compliant with WTO law. And yet, this 'success story' should not lead us to overstate neither the degree to which third parties have accepted the EU's eagerness to assume exclusive responsibility for breaches of WTO law by its Member States, nor the relative impact of its own competence rules on determinations of EU/MS international responsibility in the WTO. The main reason calling for a more qualified assessment is that we simply do not have (as of yet) well-established authoritative WTO jurisprudence on the sensitive question of when can Member State conduct be attributed to the Union: ${ }^{168}$ as we have seen, it has been raised and adjudicated only on three occasions in WTO panel proceedings and never thus far in Appellate Body proceedings. In addition, WTO dispute settlement practice reveals that joint complaints against the EU and its Member States have not ceased, even if the Union has been granted exclusive external powers for almost all WTO matters under the Lisbon Treaty.

Nonetheless, in the three cases where EU/MS responsibility was contentious, WTO panels have categorically held that EU Member States are bound to perform all obligations incumbent upon them under the WTO Agreement (and its annexed agreements), so as long as they remain full and independent members of the WTO and irrespective of the (exclusive) powers they may have transferred to the Union in the CCP field under EU law. While this stance may grate on the ears of most EU lawyers, it is legally sound from an international law standpoint. Moreover, it also wise from a broader governance perspective: to put it bluntly, it is not for WTO dispute settlement organs to turn the W'TO Agreement de facto into a 'pure'

treatment concerned is required by Union law." (emphasis added). For a seemingly more flexible reading as incorporating all instances in which EU Member States act to implement EU law, see A. Delgado Casteleiro, 'The International Responsibility of the European Union - The EU Perspective: Between Pragmatism and Proceduralisation' (2012-2013) 15 Cambridge Journal of European Legal Studies 563, at 580-581 (referring to the "EU's normative control") and 586 (referring to "implementing EU law").

166 See Dimopoulos (2014), at 1676, noting that, unlike in the WTO dispute settlement system (where the primary remedy is not compensation), the assumption by the EU of international responsibility for all Member State acts violating investment obligations raises very significant moral hazard concerns: "Member States may act in violation of their obligations under EU [international investment agreements], knowing that compensation will be paid by the EU and (indirectly) shared by all Member States." Arguably, similar moral hazard concerns could arise with regards to retaliation in the WTO dispute settlement system, albeit this is only a secondary remedy therein (see n 152 above).

${ }^{167}$ See section 2.2 above.

${ }^{168}$ See section 3.4 above, indicating that the vast majority of the total 68 WTO disputes in which the EU was targeted as sole respondent concerned EU measures only -and not Member States measures as such- and therefore there was no ambiguity that such EU acts were attributable to the Union. 
EU agreement for the purpose of international responsibility. ${ }^{169}$ That being so, in assigning international responsibility -i.e., whether solely to the EU (EC - Computer Equipment (1998) and EC - IT Products (2010)) or jointly with (some of) its Member States (EC-Large Civil Aircraft (2011)), these WTO panels were seemingly guided by one pragmatic consideration: who has the actual power to remove (or modify) the measure found WTO-inconsistent? Therefore, it is this special feature of the WTO dispute settlement system -i.e., a clear preference for juridical restitution as a primary remedy for breaches of WTO law- that ultimately renders the internal division of competences between the EU and the Member States a relevant criterion in deciding who should be held responsible. This 'competence/remedy' model for managing EU/MS international responsibility in the WTO may thus remain a case apart, unique to that dispute settlement regime, as notably demonstrated by the more cautious EU approach emerging in the investment field.

However, and contrary to what other scholars appear to suggest, ${ }^{170}$ it is not a foregone conclusion that the EU is always the one and only entity with the actual power to provide juridical restitution in the WTO dispute settlement system, just because it has exclusive external competence for nearly all WTO matters. This is undoubtedly the case when it comes to highly harmonised segments of the CCP (e.g., tariffs and customs matters), where Member States conduct is strictly confined to implementing directly applicable EU legislation: evidently, the EU only can amend/withdraw such legislation if found WTO-inconsistent. And yet, as we have seen, it is less straightforward why the EU would also have such an exclusive remedial capacity for breaches of WTO law in cases where its normative control over Member State action is more limited, or indeed entirely absent: for instance, why couldn't the EU Member States concerned withdraw themselves their own subsidies, or regulatory measures permitted but not required by EU law, if found WTO-inconsistent? In fact, from the perspective of providing juridical restitution, it is not the division of external (i.e., treaty-making) competences between EU and Member States that is of primordial importance, but of internal (treaty-infringing/treaty-performing) competences and these are not within the exclusive regulatory domain of the Union for all subject matters covered by WTO law. ${ }^{171}$ This being so, insofar as EU Member States are targeted as a respondent in a given WTO dispute and hold the power to end an eventual breach of their WTO obligations, there is no cogent reasons why WTO dispute settlement organs should rely on EU control mechanisms ${ }^{172}$ instead of making them directly responsible and accountable under WTO law. Indeed, it could be argued that this would not only make little sense from an international law perspective, but also be undesirable for intra-EU 'fairness' considerations. To retake the logic underpinning the EU Regulation on financial responsibility in the ISDS context, ${ }^{173}$ why would it be any more 'fair' in the WTO for the EU alone to face the consequences of international responsibility (including possible retaliation) en bloc, when a breach of WTO law is caused by

\footnotetext{
${ }^{169}$ In a post-Lisbon setting, this would have likely been the practical consequence had WTO dispute settlement organs accepted the Commission's proposition (supported by some EU law scholars) that the apportionment of obligations should strictly follow the distribution of external competences under EU law and be the decisive factor in assigning international responsibility (see section 2.2 above)

170 See note 130 above.

${ }^{171}$ See sections 2.3 and 4.1 above, pointing to several policy areas covered by WTO law where there has been (as of yet) no full harmonisation of national laws, because they have been only partially regulated at EU level (e.g., minimum standard Directives in the areas of consumer and environmental protection), or even not at all (e.g., certain forms of internal taxation).

172 Again, doing so would de facto turn the WTO Agreement into a 'pure' EU agreement, whereby EU Member States are not seen as WTO members in their own right and bearers of the contractual obligations, but mere vehicles for carrying out the EU's obligations under WTO law.

173 Regulation (EU) No 912/2014, paragraph 5 of the Preamble, discussed in section 4.2 above.
} 
the discretionary (i.e., where EU law merely authorises) or fully autonomous (i.e., where there is no EU legislation) decision of one (or some) of its Member States?

In closing, it is important to underline that the issue of EU/MS international responsibility in the WTO is not, of course, a purely legal question but one highly political for all players involved. For the EU, the capacity to speak with one voice and assert its exclusive responsibility in the WTO dispute settlement system is certainly instrumental in forging its own identity as a leading trade actor and power on the global stage, ${ }^{174}$ but also important at a more practical level. ${ }^{175}$ At the same time, it appears politically unviable for (some) EU Member States to even consider relinquishing their independent membership of the WTO. ${ }^{176}$ For their part, other W'TO members may target the EU and its Member States jointly as respondents not solely out of genuine legal concerns, ${ }^{177}$ but strategically as a means to challenge the Union's unity and leadership in the WTO. ${ }^{178}$ In these circumstances, the EU and its Member States may increasingly find themselves at a crossroad between maintaining their 'mixed' membership of the WTO while claiming the EU's 'exclusive' responsibility in its dispute settlement system. Indeed, aside from voting and other political considerations, ${ }^{179}$ one may well question whether there is still a legal need, as a matter of EU law, ${ }^{180}$ for the parallel double EU/MS membership of the WTO members: in other words, have EU exclusive powers under the CCP now become sufficiently broad for the Union to assume alone the obligations of WTO membership? ${ }^{181}$ And if so, does it have effective internal mechanisms at its disposal to ensure implementation of those obligations by its Member States? ${ }^{182}$ It is not the purpose of the present chapter to engage with these convoluted questions of EU law, nor

174 See inter alia, Baetens, Kreijen and Varga (2014), at 1244; Delgado Casteleiro and Larik (2013), at 255.

175 See Kuijper (2010), at 224, arguing that "[f]or practical reasons, there can be no question of drafting submissions to WTO Panels and Appellate Body in a commission consisting of the Commission and all the Member States: it would be the death of any coherent application or defence before these jurisdictional organs." ${ }^{176}$ See e.g., see M. Hanh and L. Danieli, 'You'll Never Walk Alone: the European Union and its Member States in the WTO' in M. Bungenberg and C. Herrmann (eds.), European Yearbook of International Economic Law - Common Commercial Policy After Lisbon (Springer, special issue, 2013), at 63 arguing that it could even cause "a constitutional crisis" in some EU Member States (e.g., Germany if the Lisbon Treaty was interpreted as requiring their withdrawal from the WTO.

177 Arguably, the EC - Large Civil Aircraft (2011) case could be cited as an example here.

178 Arguably, the EC - Computer Equipment (1998) and EC - IT Products (2010) cases could be seen as an example of the US 'divide and rule' strategy: see Billiet (2005), at 199.

${ }^{179}$ Pursuant to Article IX(1) WTO Agreement, the EU does not just have one vote in WTO decision-making but a number of votes equal to the number of its Member States (i.e., 28 at present). In reality, this 'greater voting power' has thus far been of limited value given to the consensus-based WTO decision-making practice. However, the W'TO Agreement does provide for the possibility to resort to voting and, from this perspective, the EU may not want to give up its current advantage should WTO decision-making practice move away from consensus in the future. On this point, see M. Bungenberg, 'Going Global? The EU Common Commercial Policy after Lisbon' in C. Herrmann and J.P. Terhechte (eds.), European Yearbook of International Economic Law (Springer, 2010), at 134-135; Hanh and Danieli (2013), at 53-54.

${ }^{180}$ In principle, from a WTO law perspective, any member may unilaterally withdraw from the WTO, six months after the written notice of withdrawal is received by the Director-General (Article XV(1) WTO Agreement).

${ }^{181}$ From an EU law perspective, besides the exclusion of transport services from the scope of the CCP (see n 22 above), EU Member States seem to attach particular significance to the fact that they (not the EU) contribute to the WTO budget to justify their continued participation in the organisation: see e.g., WTO Trade Policy Review Body, 'Trade Policy Review - Report by the European Union' (WT/TPR/G/248), dated 1 June 2011, at 6 (footnote 2) noting that "Member States maintain an active role in the Committee on Budget, Finance and Administration" after the entry into force of the Lisbon Treaty. However, see Opinion 1/94, para. 21, where the Court already opined: "Given that the WTO is an international organization which will have only an operating budget and not a financial policy instrument, the fact that the Member States will bear some of its expenses cannot, on any view, of itself justify participation of the Member States in the conclusion of the WTO Agreement."

182 On this point, see n 151 above. 
to take a position on the highly controversial and politically sensitive issue of whether the Member States should remain WTO members in their own right. ${ }^{183}$ What is here submitted is that it is for the EU and its Member States to address these matters in-house, and meanwhile the WTO dispute settlement organs have made a judicious choice not to interfere.

183 In favour of preserving the status quo, see e.g., Hanh and Danieli (2013), at 61-63. For a seemingly different view, see among others, Bungenberg (2010), at 134. 